\title{
إجراعات مقترحة لتفعيل مسئولية الإدارة الجامعية نحو نشر ثقافة التسامح لدى طلابها
}

\section{إعــاد}

د/ عزه أحمد صادق علي

مدرس التربية المقارنة والإدارة التعليمبة التهانة
أ.م.د/ محمد سيا محمد السيد

أستاذ التربية المقارنة والإدارة التعليمية المساعد

كلية التربية بقنا - جامعة جنوب الو ادي كلية التربية بقنا - جامعة جنوب الوادي 


\section{المستخلص : - (الم:}

تتاول البحث مسئولية الإدارة الجامعية نحو نشر ثقافة التسامح لاى طلابها

نظر اً لأهمية موضوع التسامح، خاصة فــي هـــهـ الآونـــة التاريخيــة المليئــة

بالصر اعات وحوادث العنف، و الثورات و الانفتاح على العالم، ولتحقيق أهــداف البحث استخدم البحث المنهج الوصفي، ثم عرض البحث إطاراً نظرياً تتاول فيه: مفهوم ثقافة التسامح و أهميتها، وموقعها في الفكر التربوي منمثلاً في آراء بعض الفلاسفة و المربين، ومن منظور الإسـام، ثم تتاول عرضــاً تحليليــاً لمســـولية الإدارة الجامعية نحو نشر ثقافة التسامح، وفي المحــور الأخيـر قــدم البحـــث إجر اءات مقترحة لتفعيل مسئولية الإدارة الجامعية نحو نشر ثقافة التسامح. الكلمات المفتاحية: الإدارة الجامعية، ثقافة التسامح. 
إجراءات مقترحة لتفعيل مسئولية الإدارة الجامعية نحو نشر ثقافة التسامح لاى طلابها

Proposed Procedures for activating The Responsibility of The University Administration Towards Spreading Tolerance Culture of its students

\title{
Dr. Mohamed Sayed Mohamed EI Sayed
}

Dr. Azza Ahmed Sadek Ali

\begin{abstract}
The research has dealt with the responsibility of the university administration towards Spreading tolerance culture of its students, because of the importance of the theme of tolerance espeacially in the resent historical times that filled with conflicts and incidents of violence, revolutions and openness to the world, To achieve the objectives, th research used a descriptive approach, The research presented a conceptual framework which dealt with: concept and importance of tolerance culture, and its place in the educational thought represented in the views of some philosophers and educators, also from the perspective of Islam, then it analysed the responsibility of the university administration towards Spreading tolerance culture, In the last axis, the research provided a proposed Procedures for activating the responsibility of university administration towards Spreading tolerance culture of its students.
\end{abstract}

Key Words: The University Administration, Tolerance Culture. 
إجراءات مقترحة لتفعيل مسئولية الإدارة الجامعية نحو نثر ثقافة التسامح لاى طلابها

يتسم العصر الحالي بالعديد من التغيرات و التطورات المســتمرة و المتز ايــدة علــى

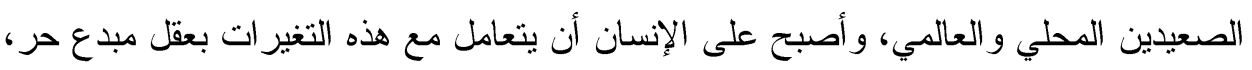

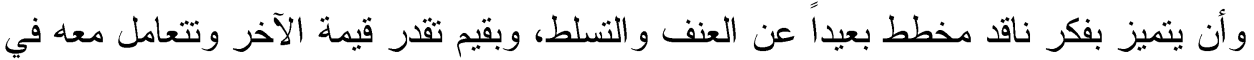

$$
\text { إطار من القبول و التسامح. }
$$

إن التسامح حسب الحوار السائد؛ هو عماد المجتمعات الديمقر اطية، فهو يمكن الأفراد

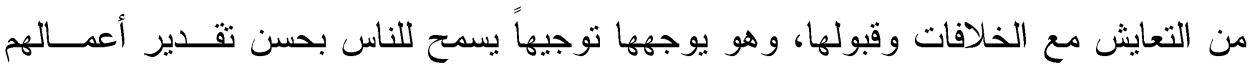

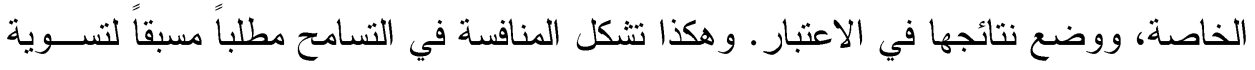

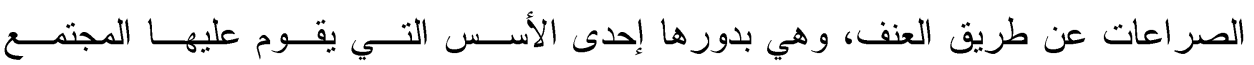

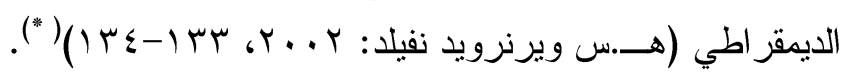

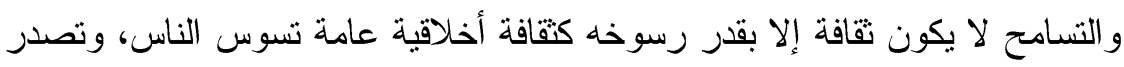

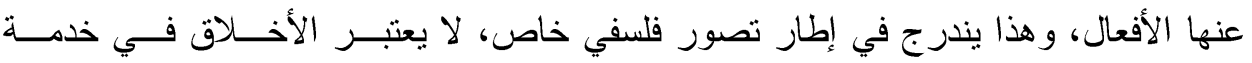

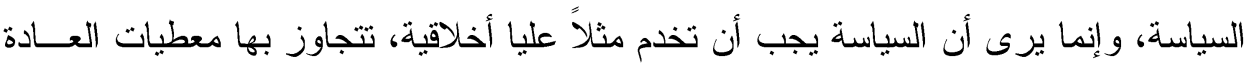

$$
\text { و الفطرة و الطبيعة (عصام عبد الله: V.... Y، T). }
$$

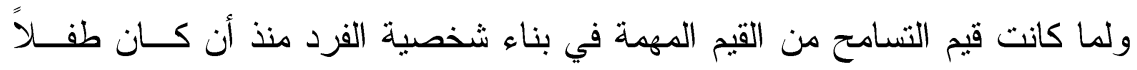

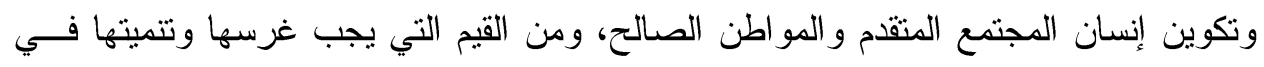

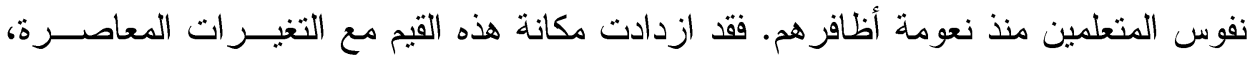

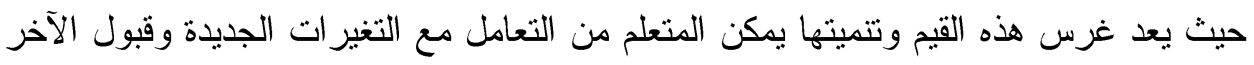

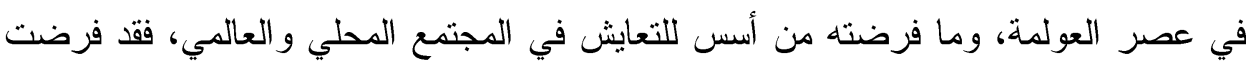

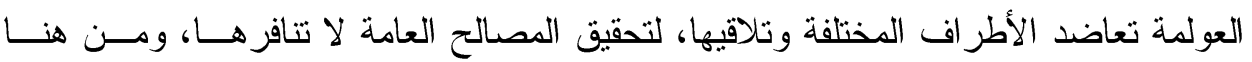

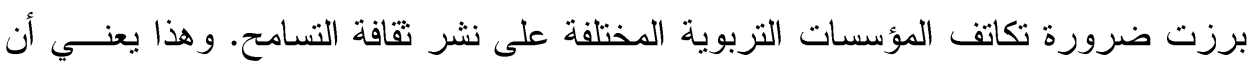

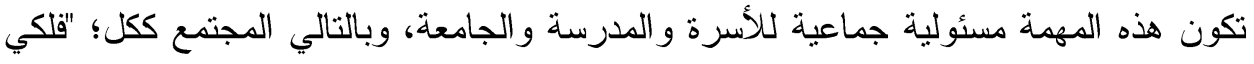

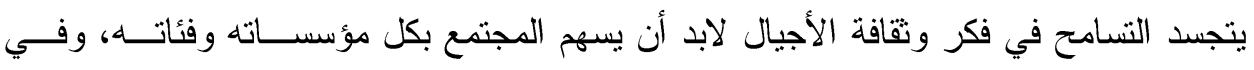

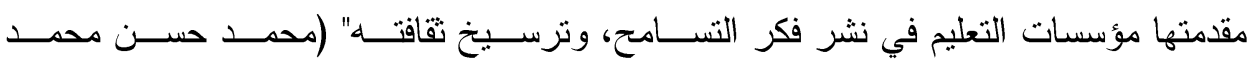

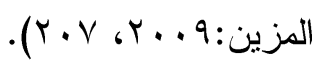
الحديث عن النسامح و الدعوة إلى إقرار مبادئه و إثشاعة قيمه و أخلاقياته ليس حـديثاً

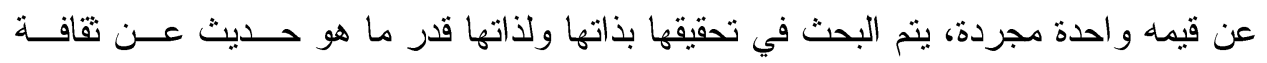

(") يثبير الرقم الأول إلى سنة النثر، والرقم الثاني إلى رقم الصفحة . 
إجراعات مقترحة لتفعيل مسئولية الإدارة الجامعية نحو نشر ثقافة التسامح لاى طلابها

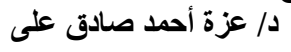

متكاملة تنطوي على العديد من الأبعاد التي تستهدف التغيير في محاولة الكثف عن المضامين

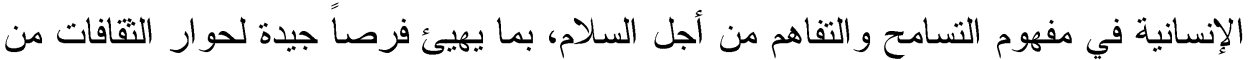
أجل بناء مستقبل الحضارة البشرية .

وهذا يأتي من منطلق أن مسار العولمة وحركة التطور العــالمي المصــاحبة لهــا،

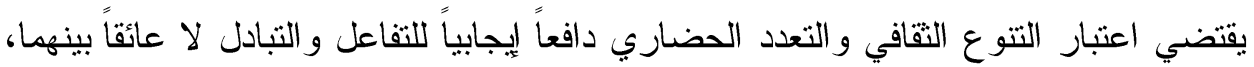
في إطار الخصوصيات التقافية و الحضارية واحتز امها، وفى ظل عالم تحول إلى قرية كونيــة

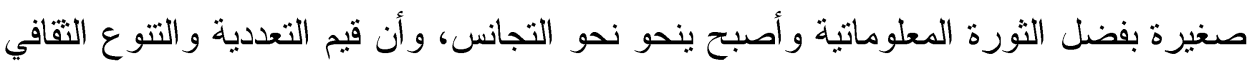

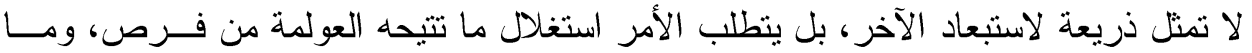
تتطوي عليه من إمكانات لدعم التضامن و التعاون و العيش المشترك بين الثعوب.

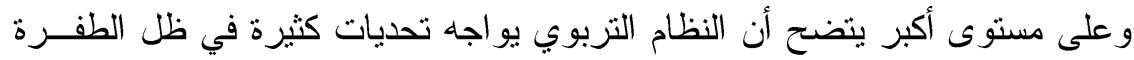

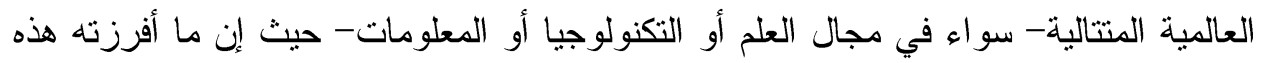

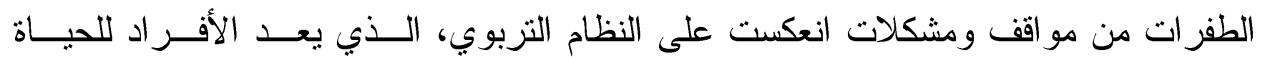

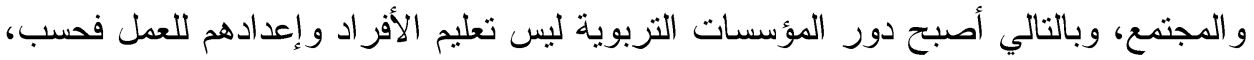

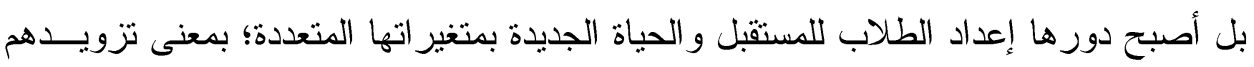

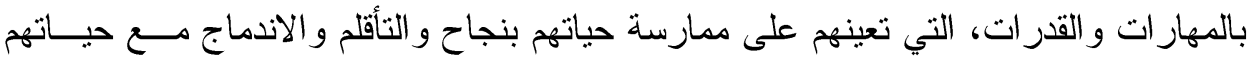

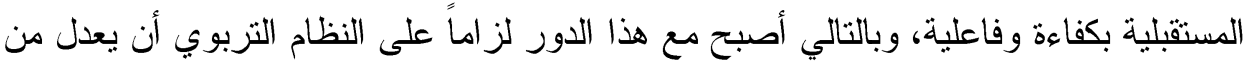

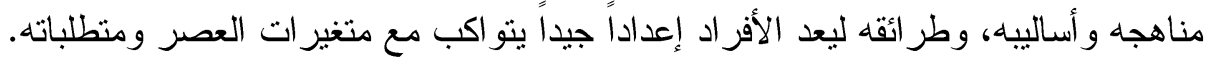

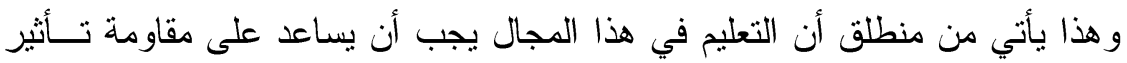
العو امل المؤدية إلى الخوف من الآخرين، ومساعدة النشء على تتمية قدر اتهم على اســنقلال

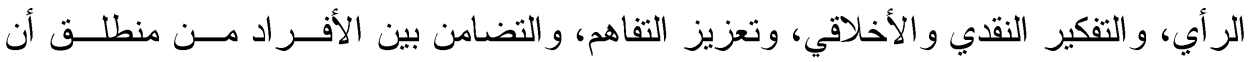

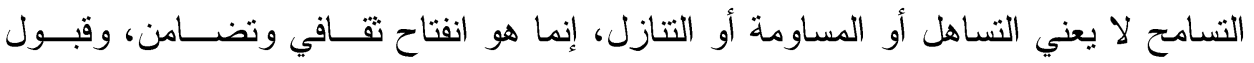

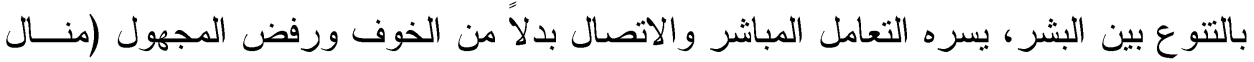

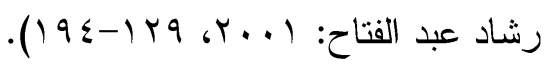

لأن التعليم يعد المجال الرحب و الواسع و الأساسي للانطلاق نحو تعزيز وتتمية نقافة

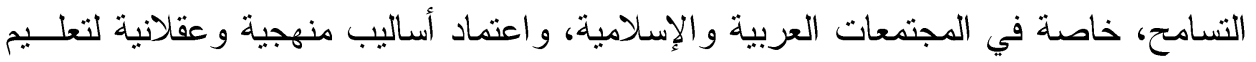

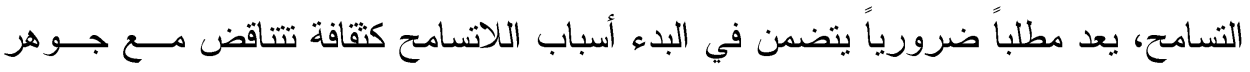
الديانات السماوية، ومن ثم البحث في جذور نقافة العنف و التطرف، وهي التقافة الأثد عـداءً

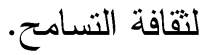


إجراءات مقترحة لتفعيل مسئولية الإدارة الجامعية نحو نثر ثقافة التسامح لاى طلابها

كما أن التعليم هو مصدر الثقافة ومنبعها، وهو الذي يبني الفــرد تربويــاً وعلميــاً

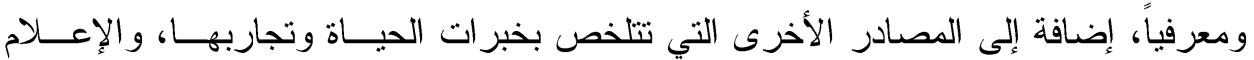

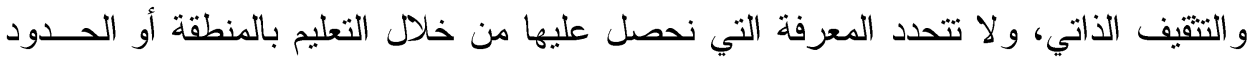

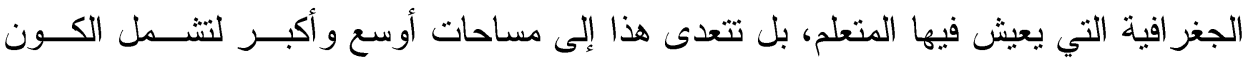

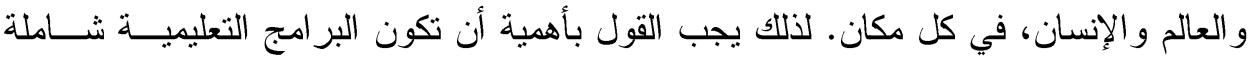

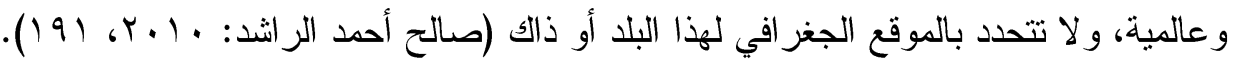

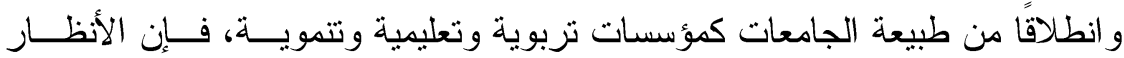

تتوجه دائمًا إليها في إعداد الكو ادر و الطاقات و القوى البشرية المؤهلة و المدربة، ونشر ثقافـــة

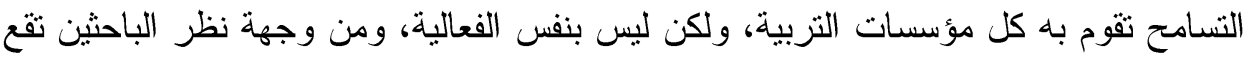

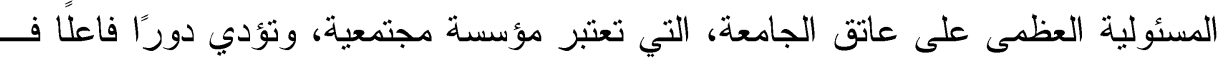

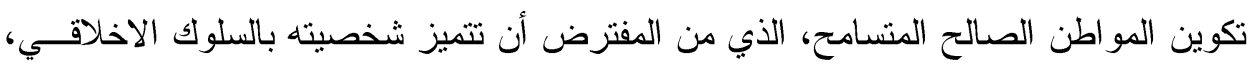

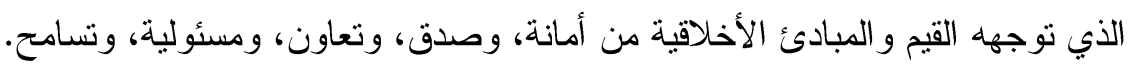

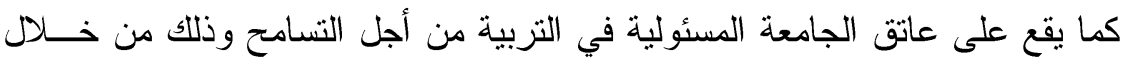

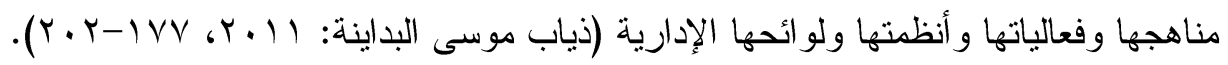

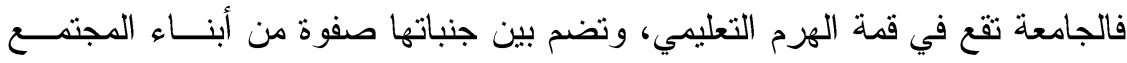

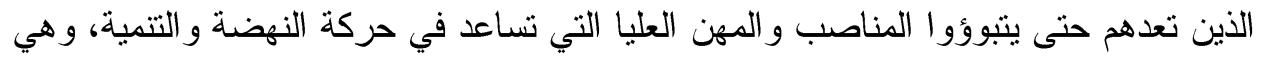

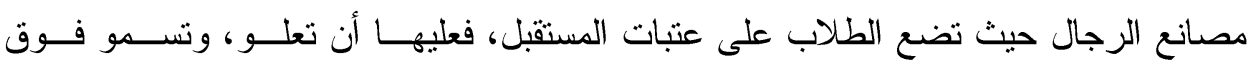

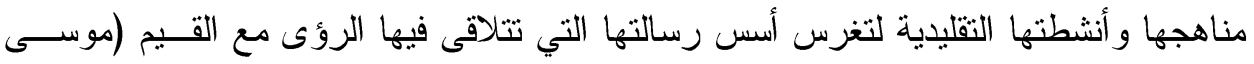

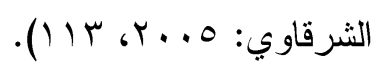

مما سبق يتضح أن العالم في أثند الحاجة إلى التسامح الفعال، و التعايش الإيجابي بين

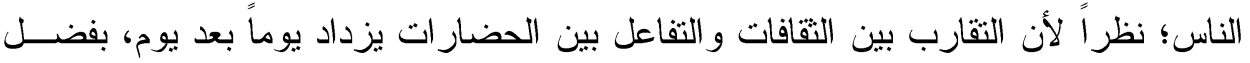

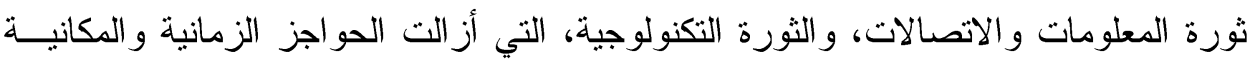

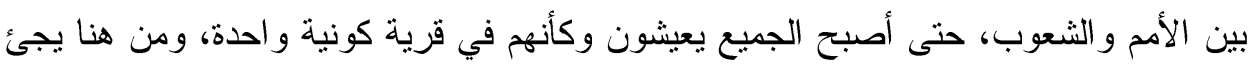

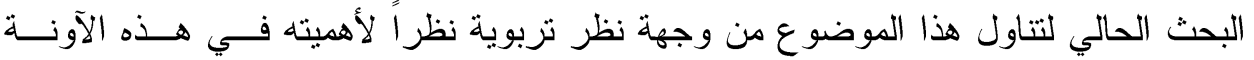

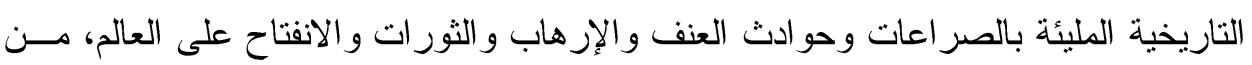

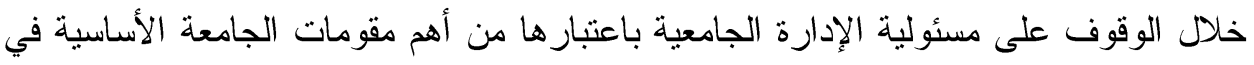

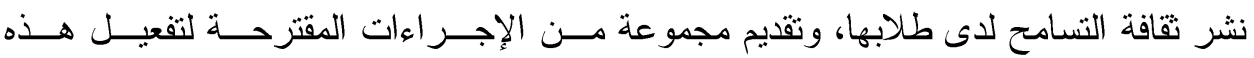


إجراعات مقترحة لتفعيل مسئولية الإدارة الجامعية نحو نشر ثقافة التسامح لاى طلابها

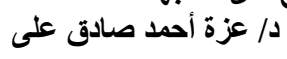

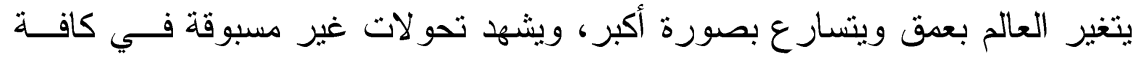
المجالات، مما يدعو لبذل جهد غير عادي لفهم عملية التغيير الجارية، والتعرف على اتجــاه تطور المجتمعات الإنسانية، وإدراك التحو لات في نظمها السياسية وقيمها الروحية، وكذلك فهر الثورة العميقة في مجالات المعرفة و التكنولوجيا، هذا الجهد و الفهم يتطلب متابعة دقيقة وناقدة،

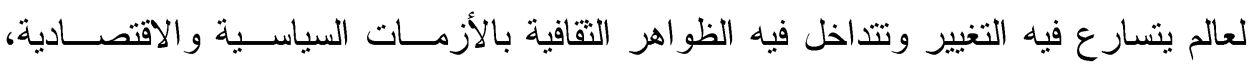

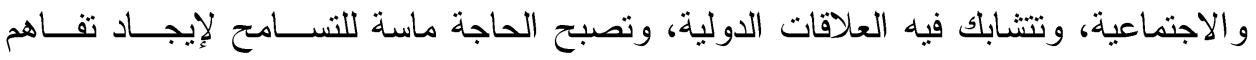
مشترك، واحتر ام متبادل بين ثقافات العالم (يوسف الحسن: Y ... Y، ع I ).

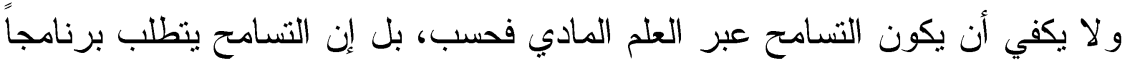

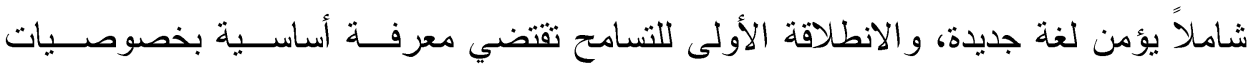

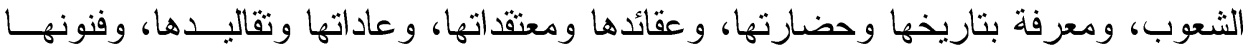

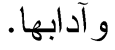

ومن ثمة فلا بديل عن التربية على الحوار واحتر ام التتوع الثقافي، وصونه، باعنباره

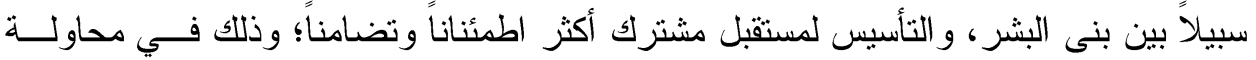

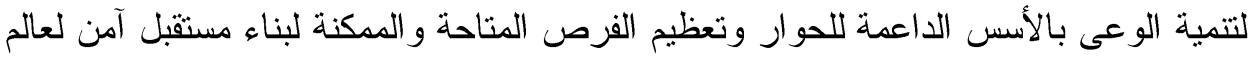
الإنسان.

في هذا الصدد نوصلت نتائج إحدى الدراسات (نادية جمال الدين: 991 (1) إلــى أن التسامح يتطلب بيئة مو اتية تدعم وجوده، وتساعد على الاقتتاع بجدو اهو وجدوى اتخاذه كموقف

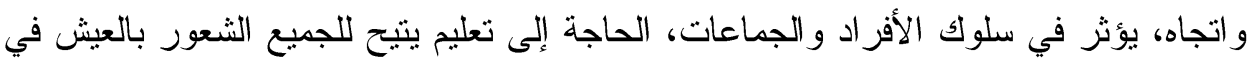

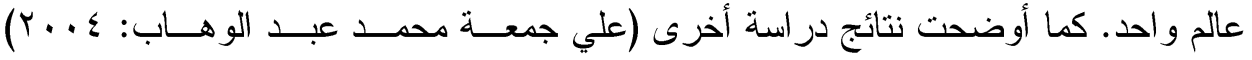

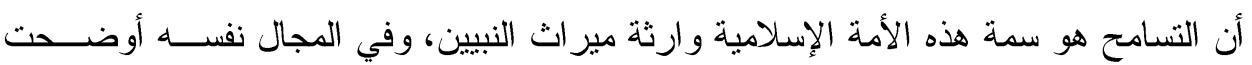

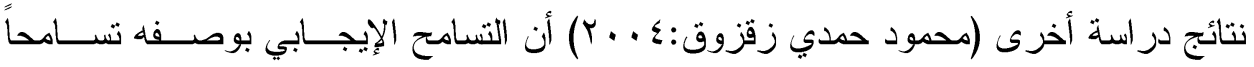

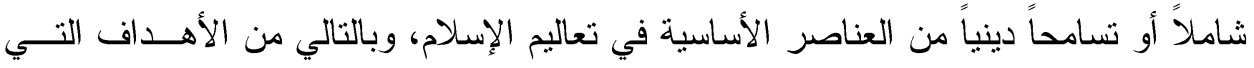

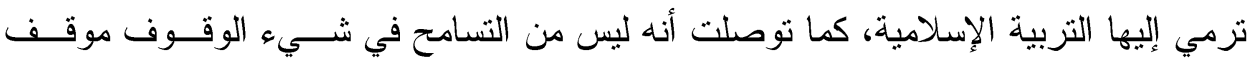

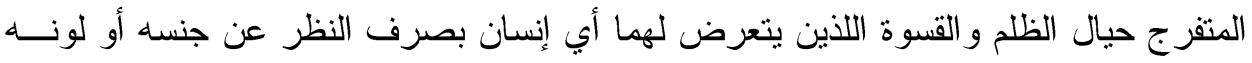

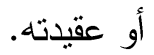

وتتجلى أهمية ثقافة التسامح كإحدى أهم الضرورات التربوية في واقع المجتمعـات

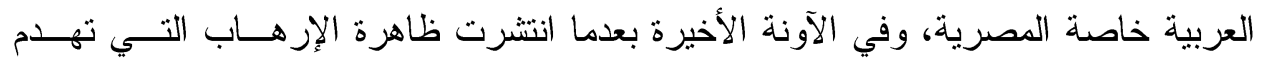


إجراعات مقترحة لتفعيل مسئولية الإدارة الجامعية نحو نشر ثقافة التسامح لاى طلابها

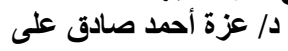

العلاقات الاجتماعية بسبب هيمنة لغة العنف على الو اقع المصري، وغياب المتل و القيم الدينية

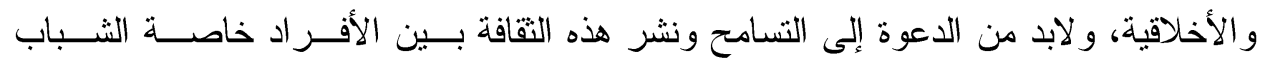
الجامعي.

حيث تعد الجامعة ممثلة في إدارتها من أهم المؤسسات التربوية و التعليمية في نشــر

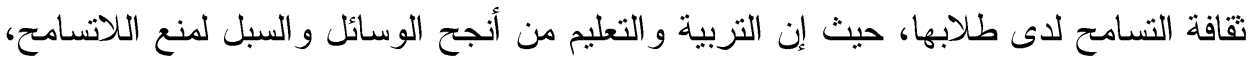

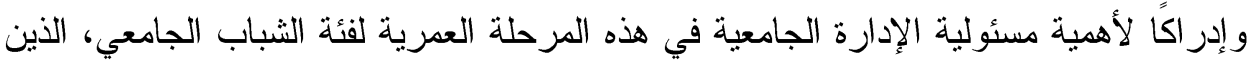

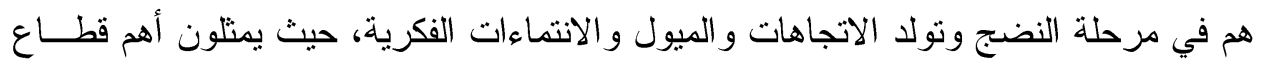
من القطاعات البشرية في المجتمع، فهم سو اعد البناء وقادة المستقبل من جانب، وهم الفئة التي

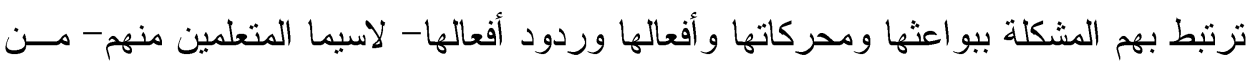

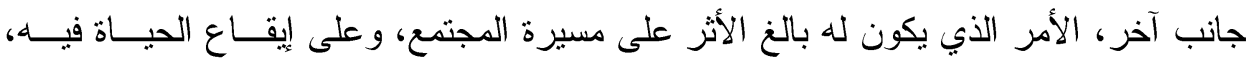
ومنظومة قيم وسلوك أفر اده.

ولعل ما تموج به الساحة العربية من ثورات شبابية تطالب بالتغيير و إسقاط الأنظمة

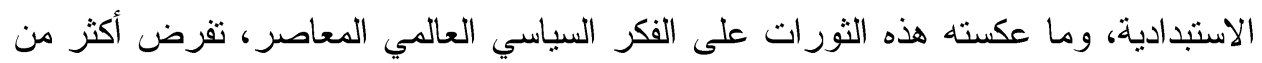

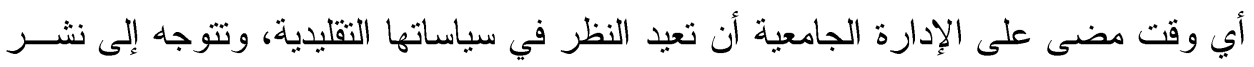

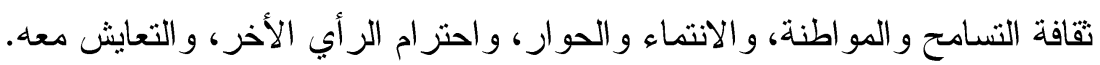

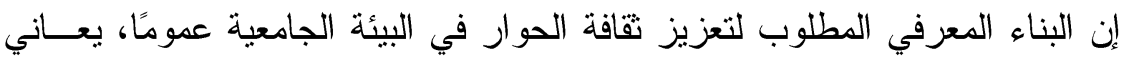

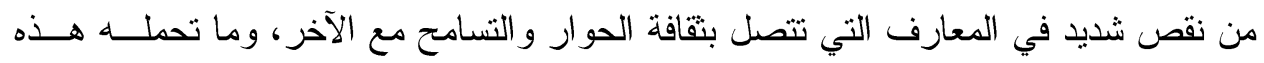

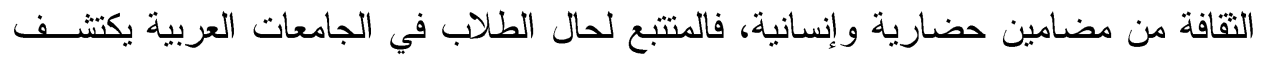

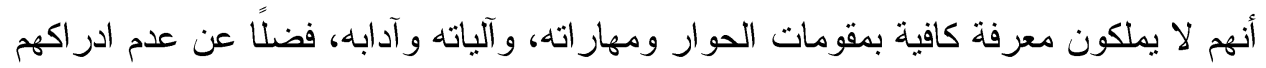

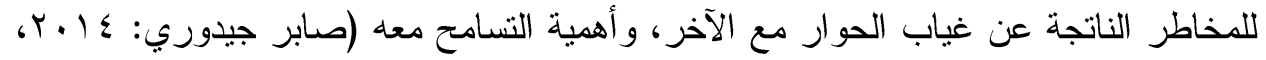

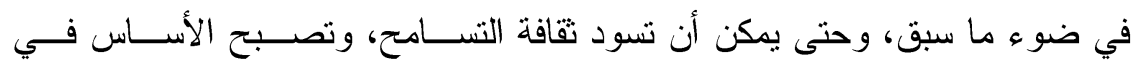

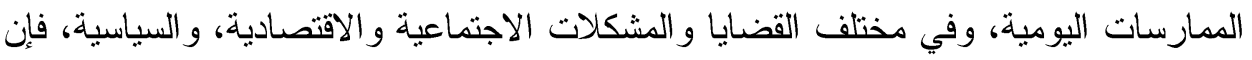
هذا بتطلب تفعيل مسئولية الإدارة الجامعية باعتبارها من أهم مقومات الجامعة الأساسية لنشر

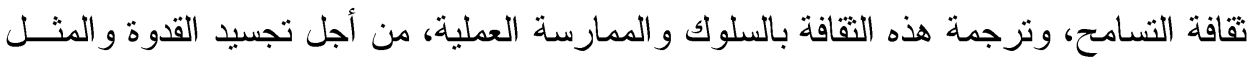
في أساتذة الجامعة، وقاداتها التربويين ومن ثم يجئ هذا البحث.

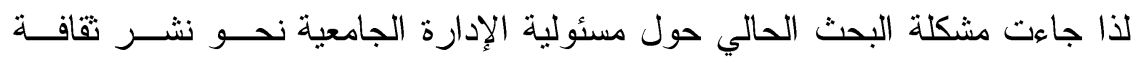
النسامح لدى طلابها وتحلدت تساؤلات البحث في الآتي: 


\section{تساؤ لات البحث:}

1- ما مفهوم نقافة النسامح؟ وما أهميتها؟

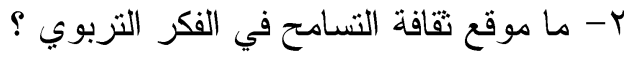

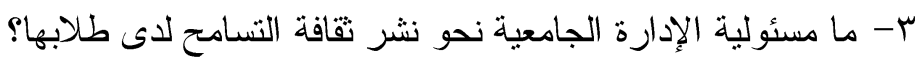

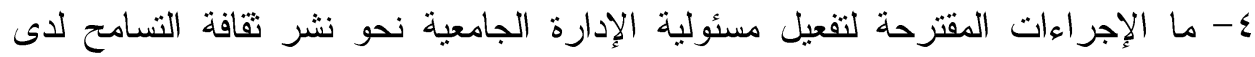

$$
\text { أهداف البحث: }
$$

1- الوقوف على مفهوم ثقافة التسامح و أهميتها. r- التعرف على موقع نقافة النسامح في الفكر التزبوي.

r- إلقاء الضوء على مسئولية الإدارة الجامعية نحو نشر نقافة التسامح لأى طلابها.

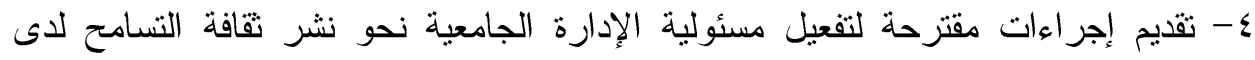

$$
\text { أهية البحثث: }
$$

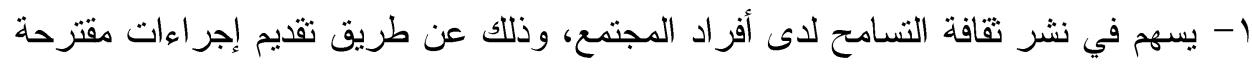
يمكن أن يستقيد منها الباحثون و المربون و القائمون على تربية الأفر اد.

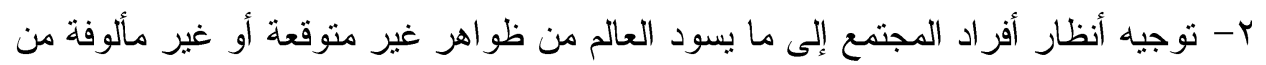
قبل.

ب- مسئولية التزبية بمؤسساتها المختلفة نحو نشر نقافة التسامح حتى تصبح بعد ذلك سلوكيات تلقائية يمارسها الفرد في حياته دون تكلف. ع- النتائج الإيجابية التي تترتب على نشر ثقافة التسامح، وتفعيلها من جانب التزبية، التي تعد دند

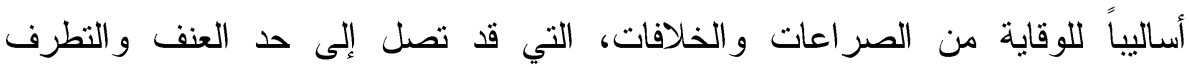

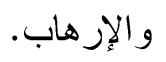

ه- تأكيد الأديان السماوية على ضرورة التآخي و التسامح والتعايش السلمي، يستلزم أن تقوم

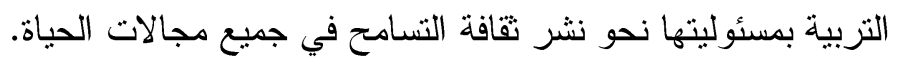

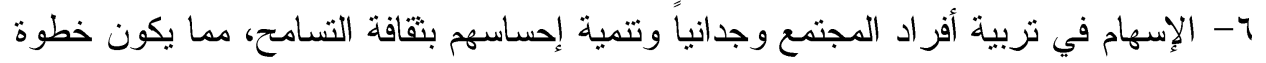
نحو الارتقاء بالمجتمع من الناحية السلوكية والأخلاقية، وسبيل من سبل الإنية الارتقاء

$$
\text { الحضاري به }
$$


إجراعات مقترحة لتفعيل مسئولية الإدارة الجامعية نحو نشر ثقافة التسامح لاى طلابها

V- يسلط الضوء على مسئولية الجامعة ممثلة في إدارتها كو احدة من أهم المؤسسات التربوية

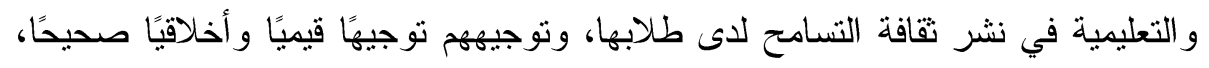

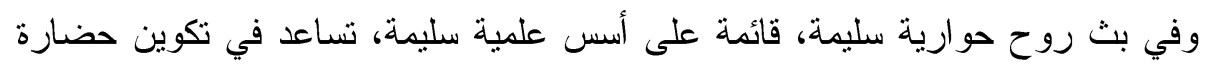

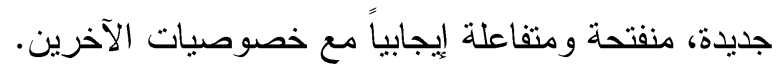
1- لنقافة التسامح دور بارز في بناء وزيادة جسور التقة والتعاون ما بين الأفراد، وبالتالي التياتي

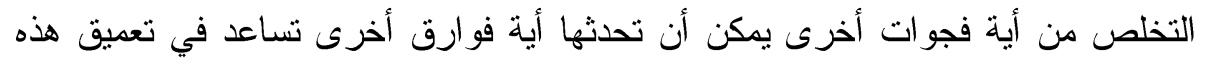

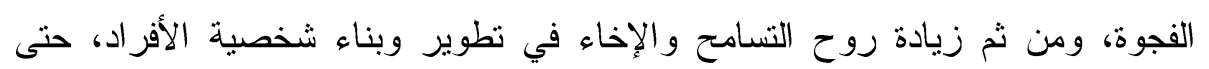

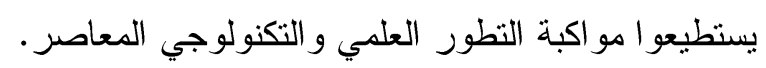

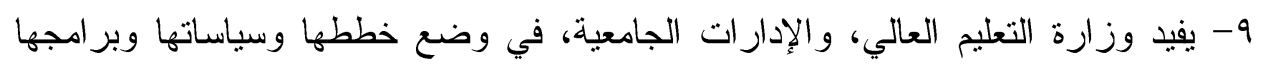
المستقبلية. • 1- يفيد الباحثين التربويين والاجتماعيين في دراسة الظواهر التربوية والمجتمعية ذات منهج البحلة: بمجتمهم.

استخدم البحث الحالي المنهج الوصفي لملاعمته لطبيعة الدراسة في وصف وتحليل الجو انب المرنبطة بمسئولية الإدارة الجامعية في نشر نقافة التسامح لاى طلابها. حدود البحث: اقتصر البحث الحالي على دراسة التسامح باعتباره مكوناً من مكونات السلوك الاجنماعي

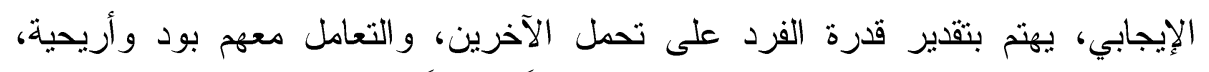

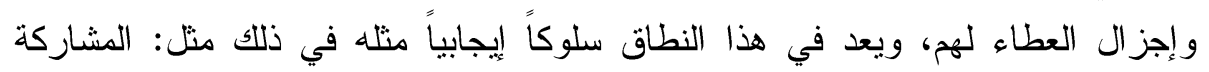
و المساعدة و الإيثار . اقتصر البحث الحالي على الإدارة الجامعية كإحدى مقومات الجامعة الأساسية التي تسهم في نشر ثقافة التسامح لدى طلابها. مصطلحات البحث:

فيما يأني تعريف المصطلحات الإنه الودة في البحث:

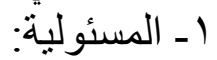

يعرف البحث الحالي المسئولية بأنها: التزام المؤسسات التربوية و التعليمية ومنها

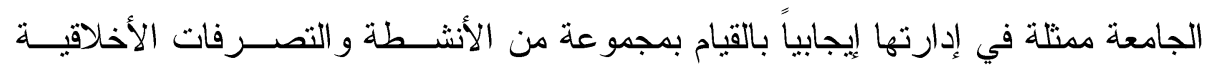
للمساهمة في نشر ثقافة التسامح لدى طلابها. 
إجراعات مقترحة لتفعيل مسئولية الإدارة الجامعية نحو نشر ثقافة التسامح لاى طلابها

الجهاز الإداري المسئول عن نوفير البيئة التزبوية والاجتماعية الصالحة للتكوين العلمي و المعرفي و المهارى و القيمي لطلاب الجامعة، وتكوين شخصياتهم، ونسقهم القيمي

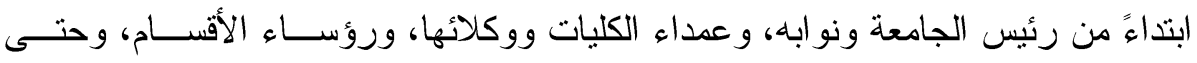
الإدارات المركزية، و إدارات الكليات و المر اكز .

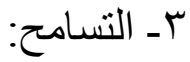

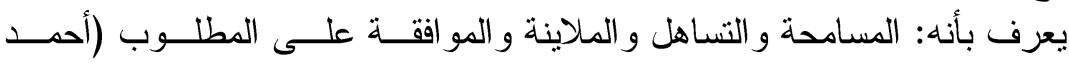

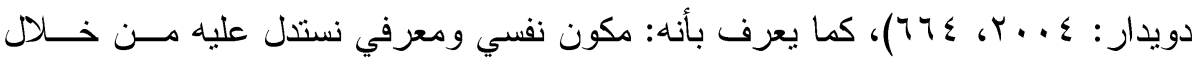

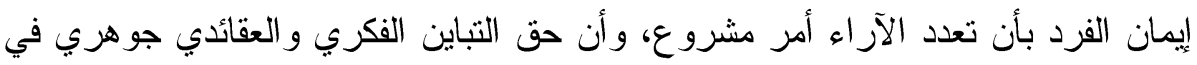

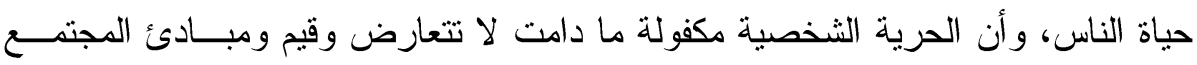

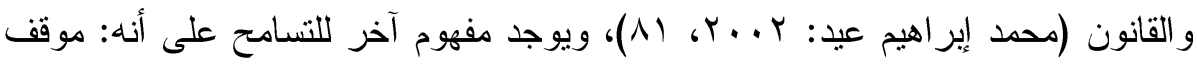

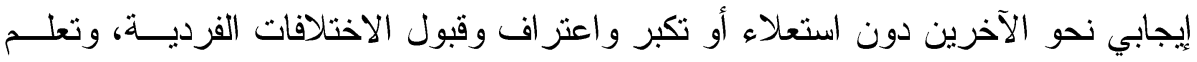

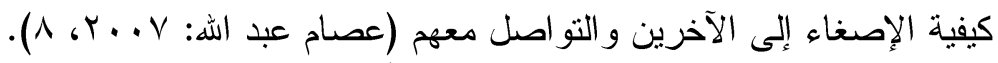

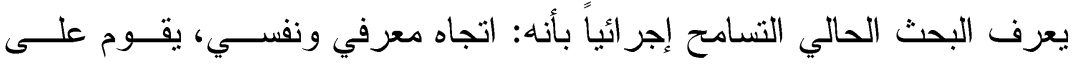

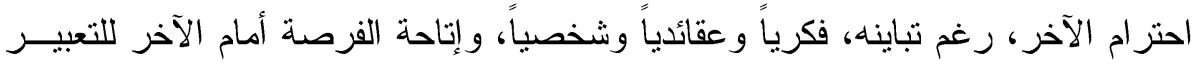

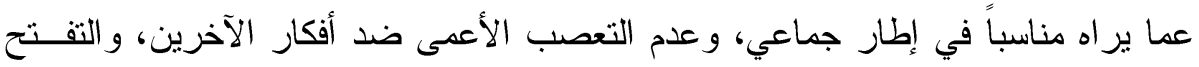
الذهني لكل ما هو جديد، وقبول الآراء المعارضة، وعام، والمناقشة الحرة.

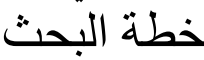

للإجابة عن تساؤلات البحث سار البحث في الخطوات الآتية:

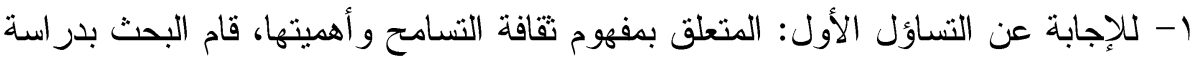

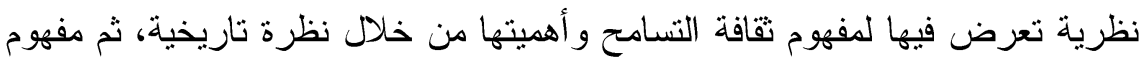

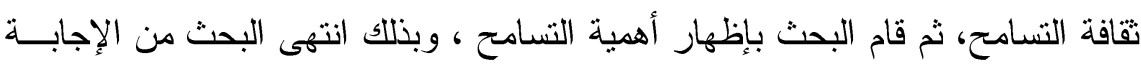
عن التساؤل الأول من تساؤ لاته. ץ- للإجابة عن التساؤل الثاني: المتعلق بموقع ثقافة التسامح في الفكر التربوي، قام البحث

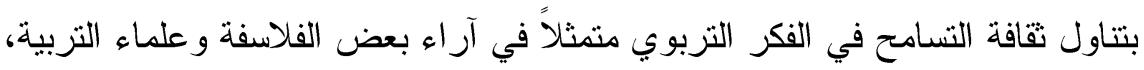

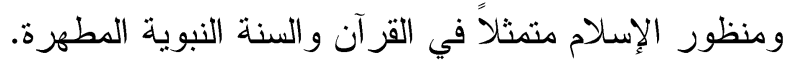

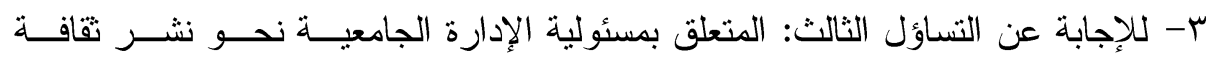
التسامح، قام البحث بعرض وتحليل لمسئولية الإدارة الجامعية نحو نشر نقافة الإدة التسامح

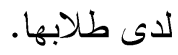
ع- للإجابة عن التساؤل الرابع: المتعلق بالإجر اءات المقترحة لتفعيـل مســئولية الإدارة

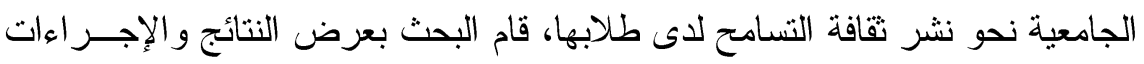




\section{المقترحة ثم التوصيات و البحوث المقترحة. الإطار النظري للبحثة}

مقدمة:

غاية التربية أن تعمل على إعداد الفرد، و إعداد المجتمع للحياة الفاضـــلة، والآخــرة

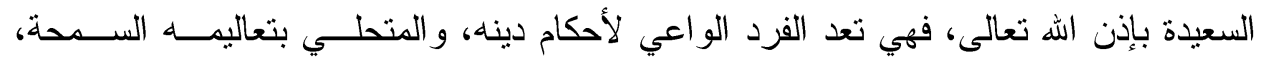

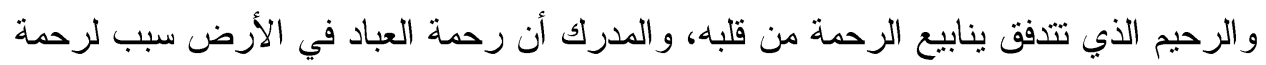
الخالق في السماء.

وهي تعد المجتمع الذي لا تقوم المعاملة بين أفــر اده علــى المؤاخـــة و المحاســـة

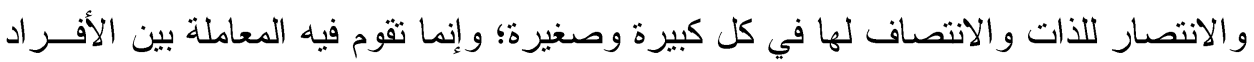

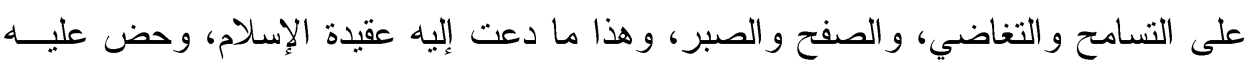

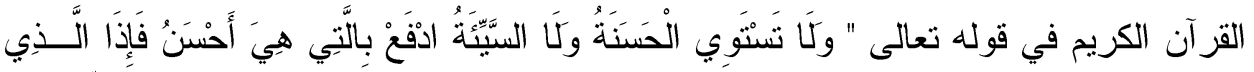

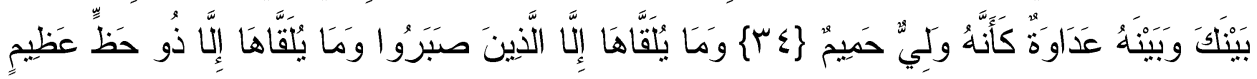

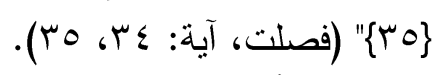

المحور الأول: ثقافة التسامح و الاهتمام بام بها - نظرة تاريخية:

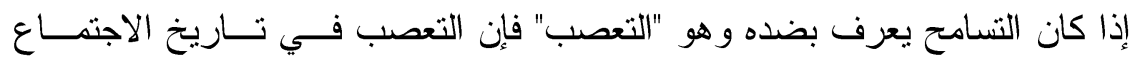
البشري هو عصب الفكرة الثمولية الأحادية - سواء كانت دينية أو وصفية - كما كان الحال

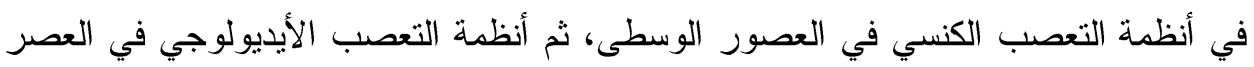

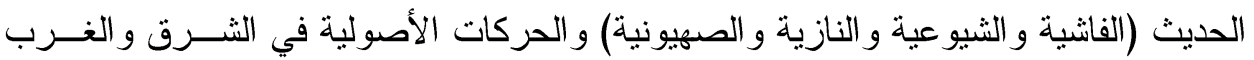

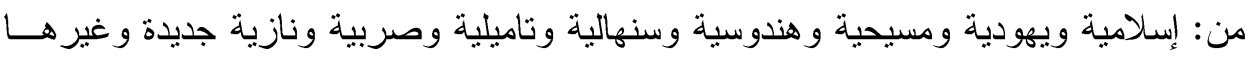

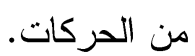

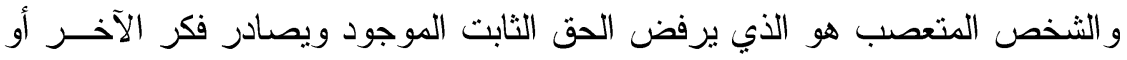
الدين الآخر، أو لا يعترف بوجود كل ما هو آخر أصلاً، سواء في الدين أو المذهب أو الطوابت الطائفة

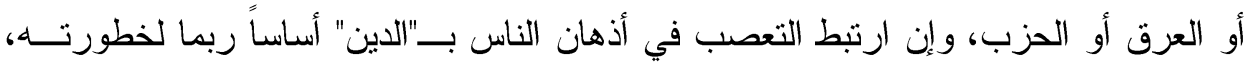

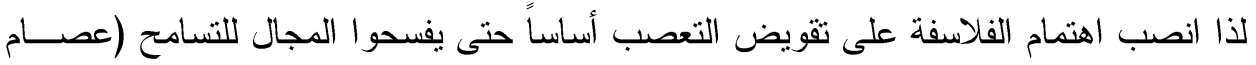

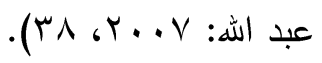

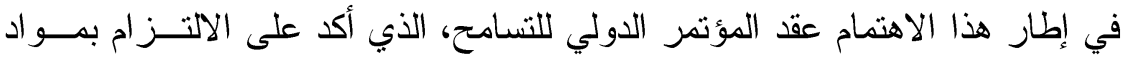
الإعلان العالمي لحقوق الإنسان و المعاهدات والاتفاقيات المتصلة به، ودعا الدول الإنى إلى تأصيل

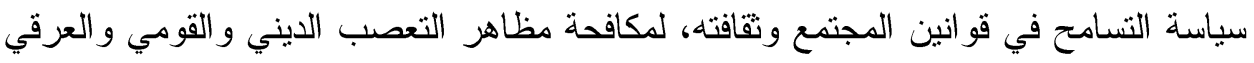

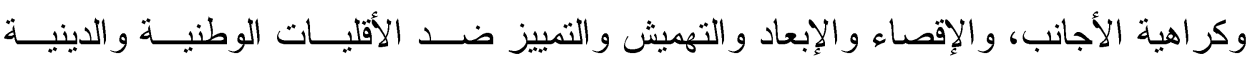




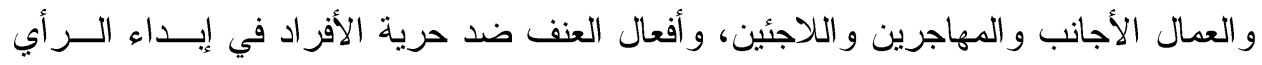

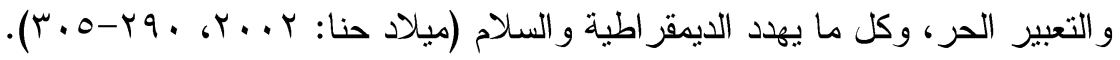

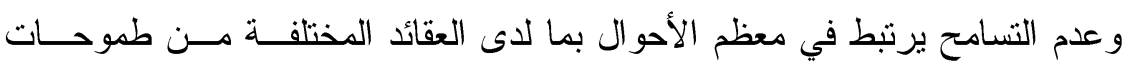

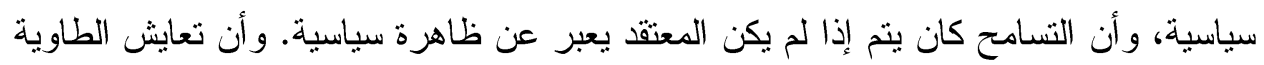

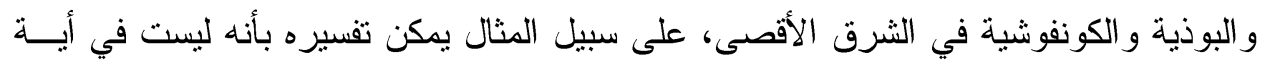

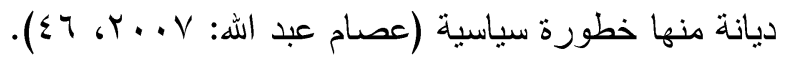

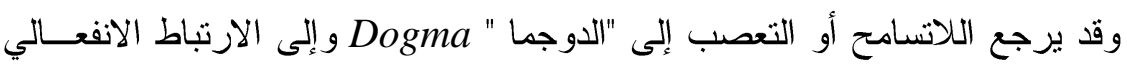

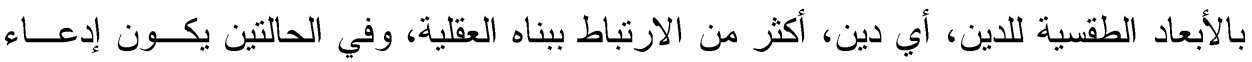

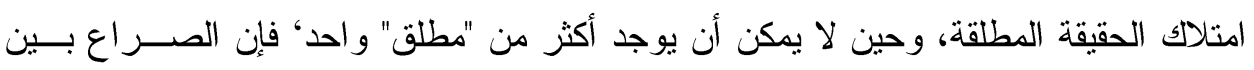

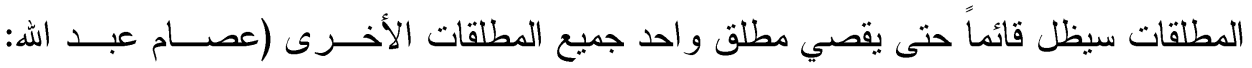

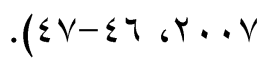

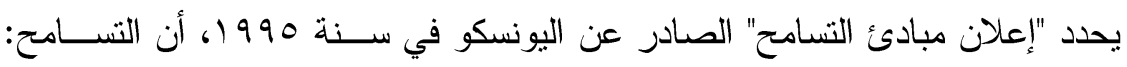

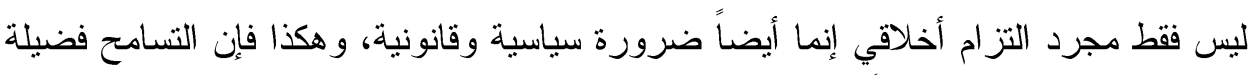

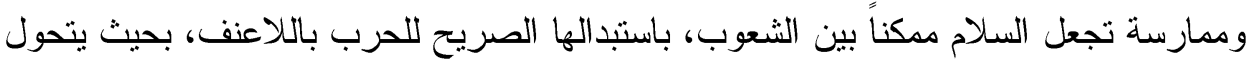

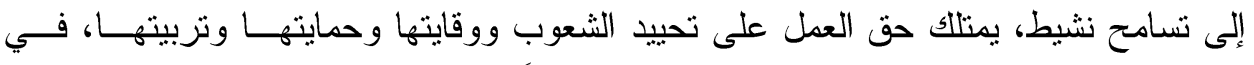

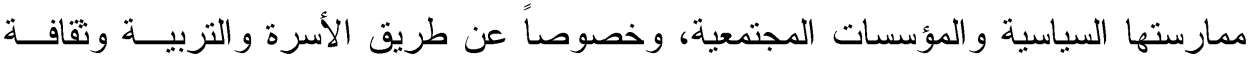

$$
\text { مفهوم التسامح : السلام (كارل بوبر : } 1997 \text { (1) 1). }
$$

للتسامح العديد من التعاريف يمكن تتاول أهمها فيما يأتي:

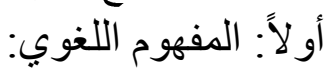

تعود كلمة التسامح في أصلها اللغوي إلى الفعل "سمح ومنه التســامح و الســماحة، ويعني "الجود"، ويقال سمح وأسمح إذا أجاد و أعطى عن كرم وسخاء، و والمسامحة المســـاهلة،

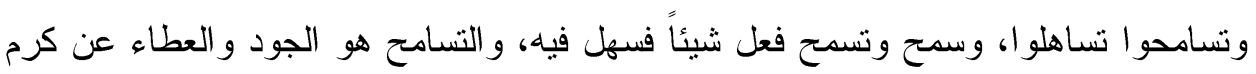

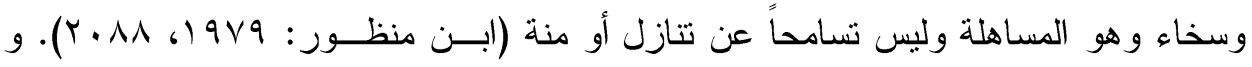

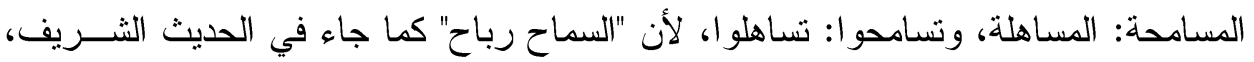

$$
\text { بمعنى أن المساهلة في الأشياء تربح صاحبها. }
$$

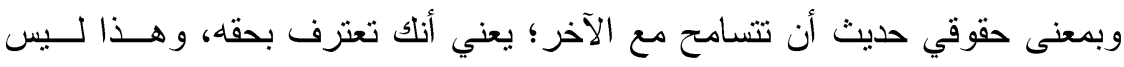

$$
\text { تتاز لاً أو خسارة، لأن السماح رباح" للك وللآخر . }
$$

ومعظم معاجم اللغة أوردت لفظة التساهل ؛ باعتبارهــــا مر ادفـــة للتســامح، يقــول 
إجراعات مقترحة لتفعيل مسئولية الإدارة الجامعية نحو نشر ثقافة التسامح لاى طلابها

"الفيروز آبادي" في "القاموس المحيط": المساهلة كالمسامحة، تسامحو ا: تساهلو ا، ساهله: ياسره

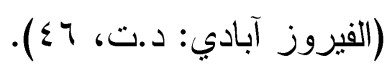

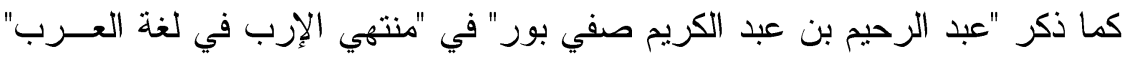

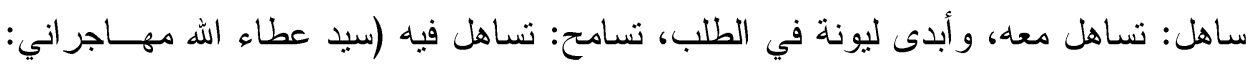

$$
\text { . ( } \varepsilon r-\varepsilon \cdot \text {. } r . .)
$$

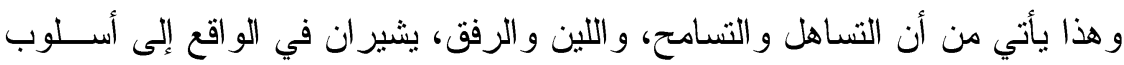

معين في التعامل، ير اد له أن يسود، ذلك أن الدين سمح و الثريعة سهلة، وهما أسلوب حياة.

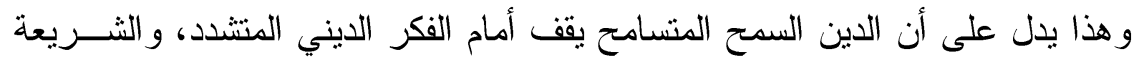

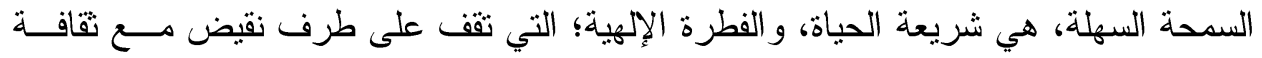

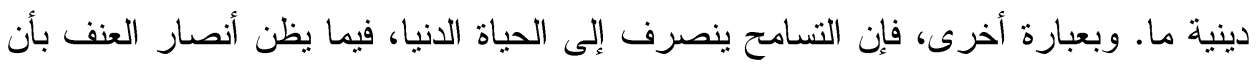
هذا الاهتمام ينصرف إلى الآخرة.

مما سبق يتضح ان التسامح ينتمي إلى سجل الفضائل ومكارم الأخلاق، التي تمتــدح في سلوك الثخص، وينصح بالتحلي بها.

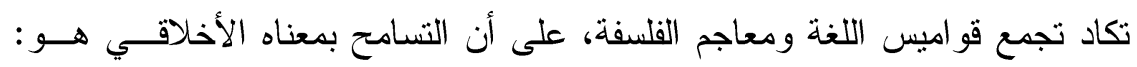
موقف فكري و عملي قو امه تقبل المو اقف الفكرية و العملية، التي تصدر من الغير، سواء كانت التهاء

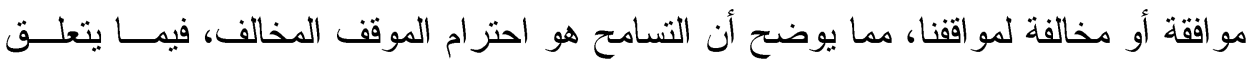

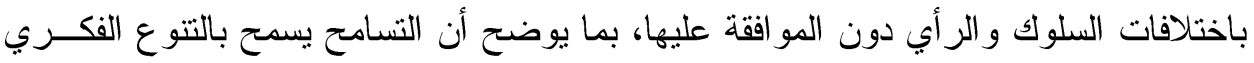
و العقائدي.

و هذا يؤكد على أن التسامح يعني تقهم أعذار الآخرين أو أخطــائهم، أو تجــاوزاتهم

$$
\text { ثانياً: المفهوم الاصدة جيدلاحي: التعامل معهم. }
$$

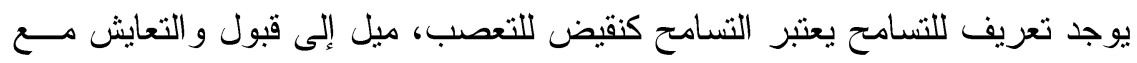

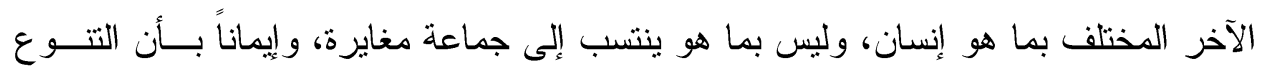

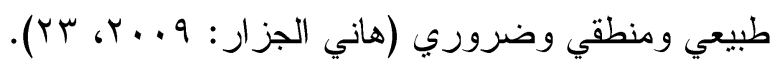

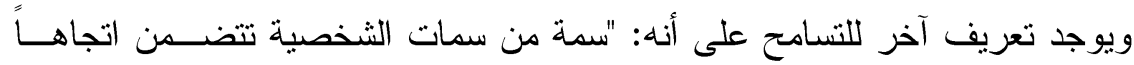

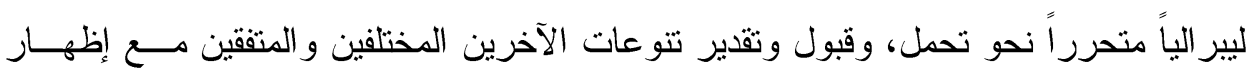

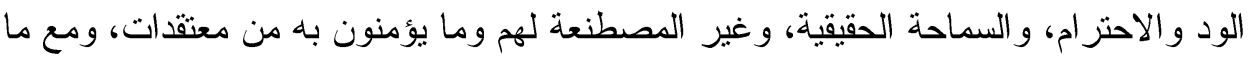

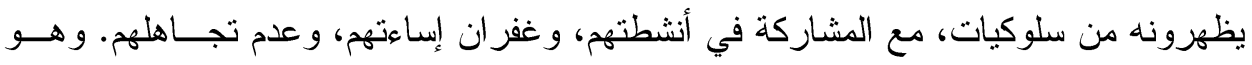


إجراعات مقترحة لتفعيل مسئولية الإدارة الجامعية نحو نشر ثقافة التسامح لاى طلابها

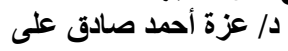

سمة نفسية وقدرة مز اجية، بر اها الفرد في نفسه، تظهر ضمن السلوكيات الاجتماعية الإيجابية،

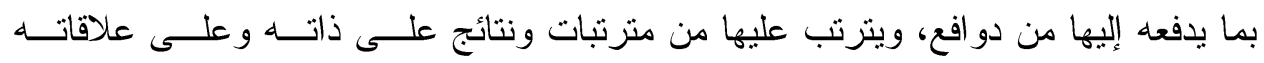

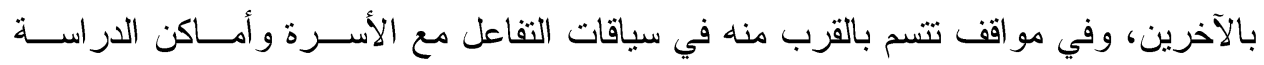

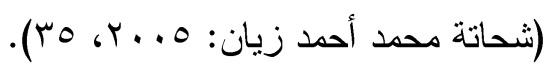

فالتسامح يعني احتر ام الآخر و القبول و التقدير للتتوع الثري لتقافات العالم وللصــفات

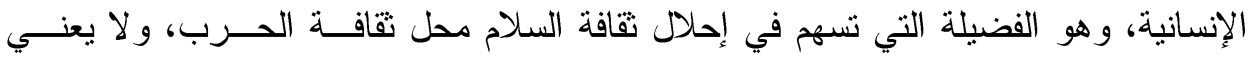

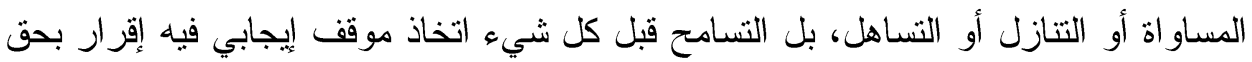

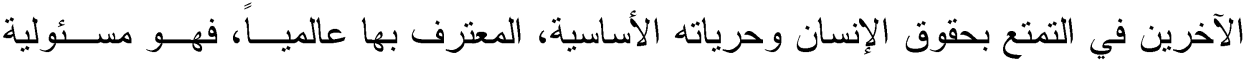
تنطوي على نبذ الاستبداد.

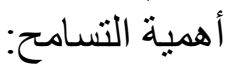

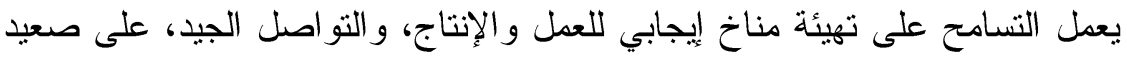

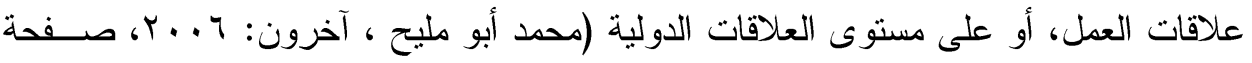
(المقدمة).

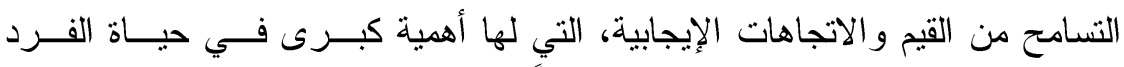

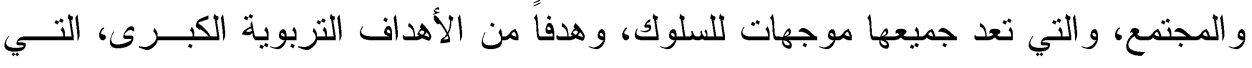
يجب على التزبية تحقيقها. الإنسان في حياته يلاقي الكثير مما يؤلمه، ويسمع الكثير مما يؤذيه، ولو تــــك كـلـل

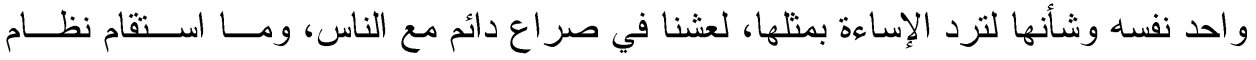

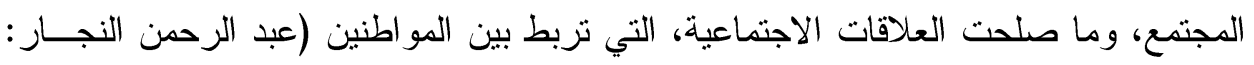
.$(1) \mathrm{r} 61917$

و هذا يوضح أن "الدعوة إلى التسامح هي دعوة للحوار و التعـايش مــع الآخــرين، و إنكار لنزعات التقوق و السيطرة، وهي نظرة لقضايا المستقبل، وتعبير عن إرادة الحضارات

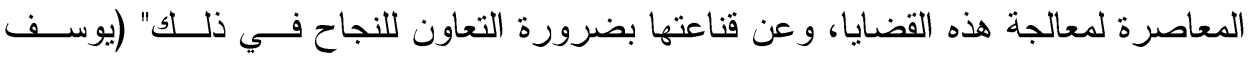

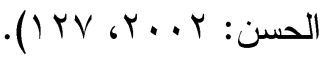

الإنسان عندما تكون نفسيته متخلقة بأخلاق الحلم و العفو ، و التنسامح فإنه يكون مــناً

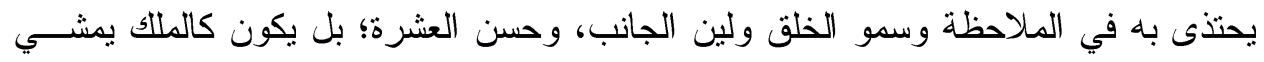

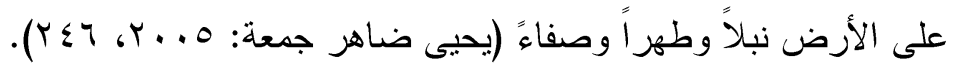
بالتالي تتضح أهمبة التسامح في الآتي:

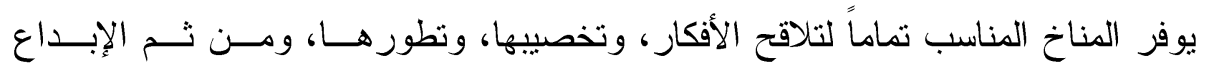




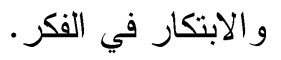

التسامح مبدأ من المبادئ الأخلاقية المهمة، التي تؤسس للعلوم من جهة، وتسبر بها العلوم

$$
\text { من جهة أخرى. }
$$

التسامح ضروري للعلوم وتقدمها.

النسامح يقيم في حياة الإنسان قسطاً كبيرًاً من السعادة و الهناء، ور احة البـال.

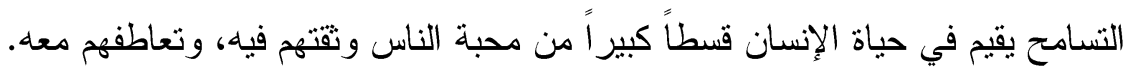
ثو اب الله تعالى في الآخرة للإنسان المتسامح، ورضاه تعالى عن هذا التسامح في الــنـيا و الآخرة.

التسامح هو أصل الو لاء في الدولة، وأصل كل خير بين أبناء الأمة الواحدة، لإزالــة

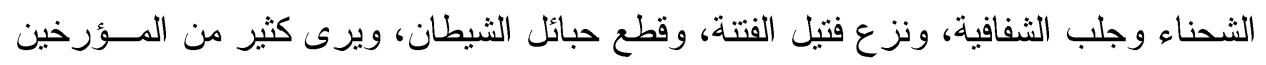

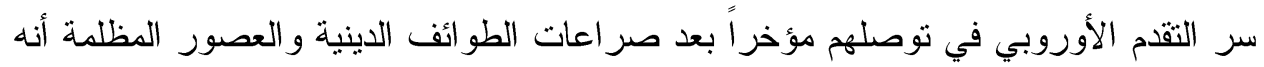

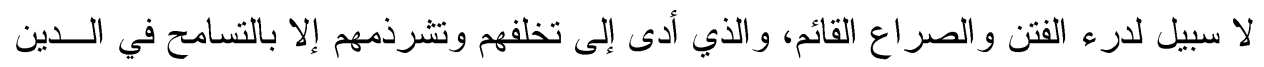

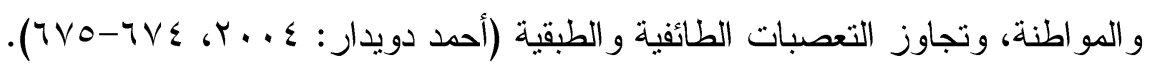

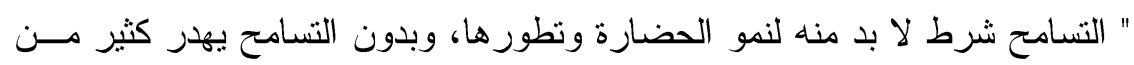

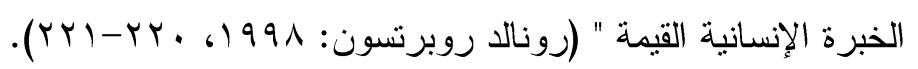

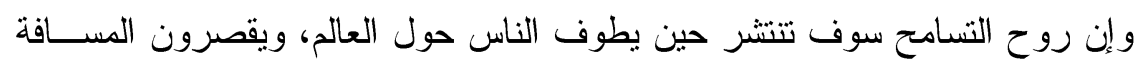

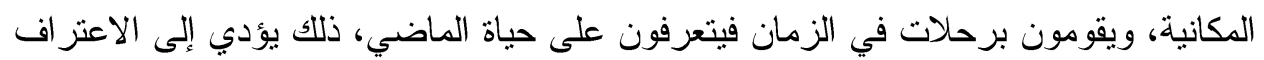

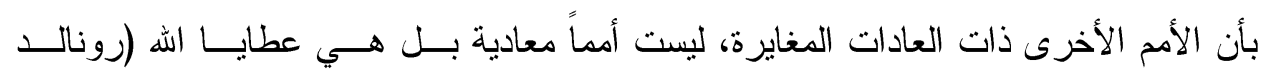

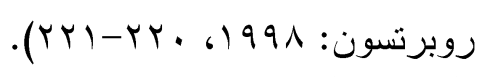

المحور الثاني: ثقافة التسامح في الفكر التربون التربوي

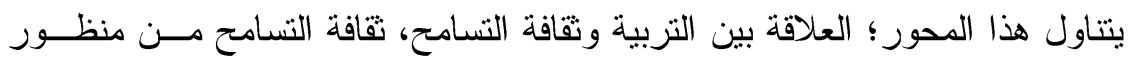

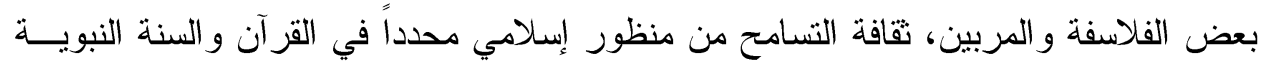

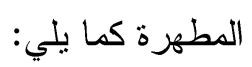

أـ العلاقة بين التربية وثقافة التسامح: التربية كعملية اجتماعية هادفة، ومن خلال عملياتها المتثابكة ونظمها الرسمية وغير الرسمية وعلى طول عمر الإنسان، بمكن أن تسهح في توفير الثروط الملائمة لعلاقات يسودها

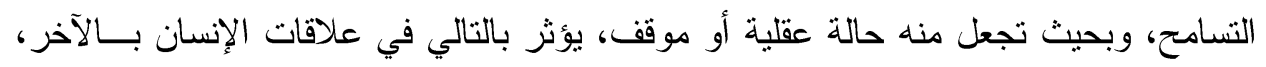

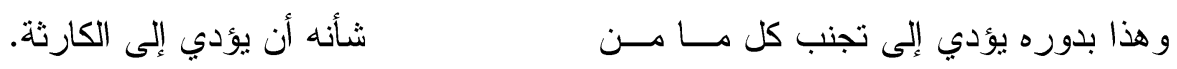


إجراءات مقترحة لتفعيل مسئولية الإدارة الجامعية نحو نثر ثقافة التسامح لدى طلابها

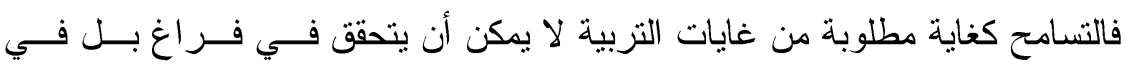

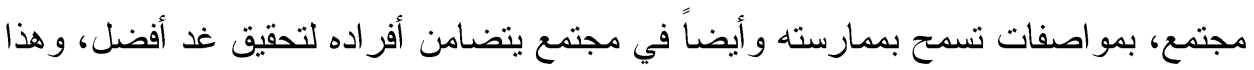

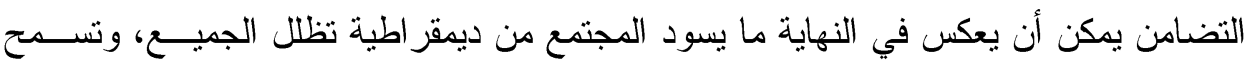

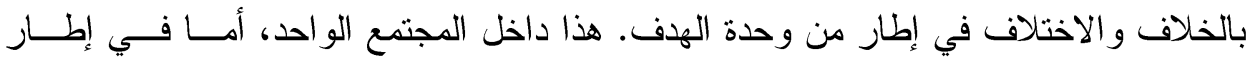

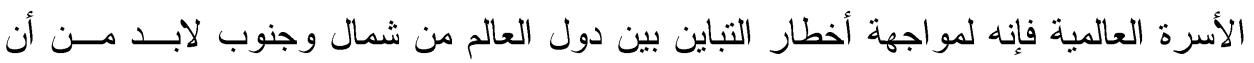

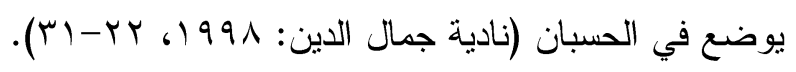

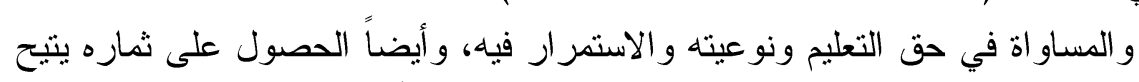

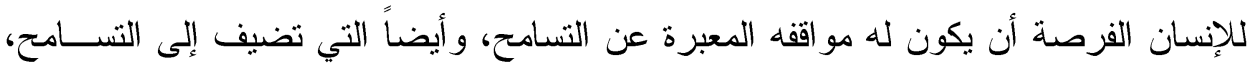
وبحيث يصبح التسامح هو نهاية المطاف النقافي للإنسان في المجتمع ككل (نادية جمال الدين: . (r)

إن الأثر التربوي للبيئة الاجتماعية ينعكس في تكوين شخصية الفرد و اتجاهاته العقلية

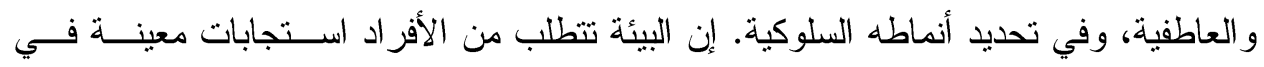

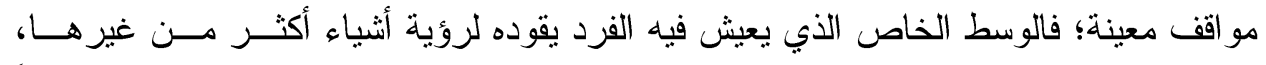

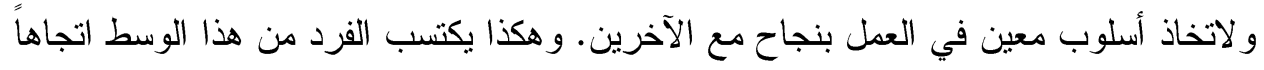

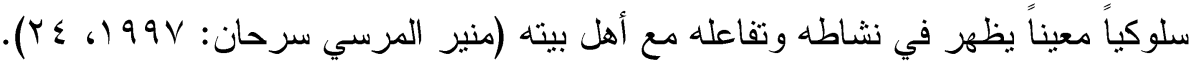

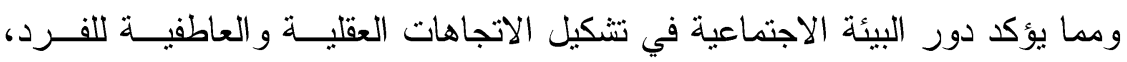

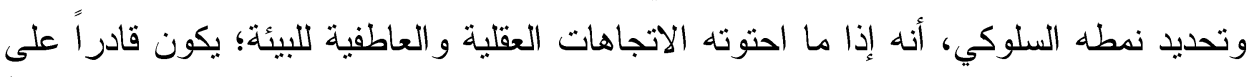

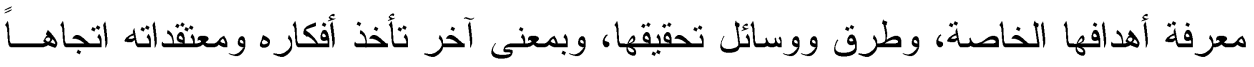

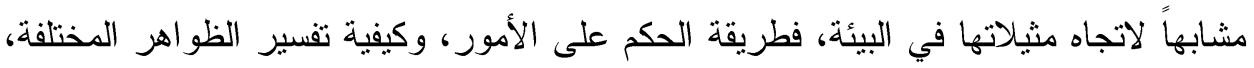

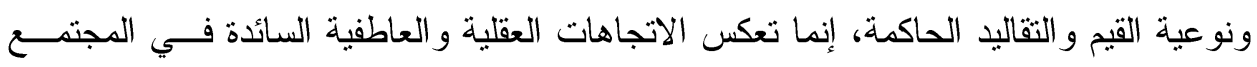

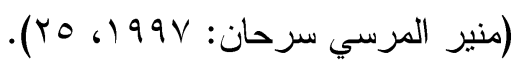

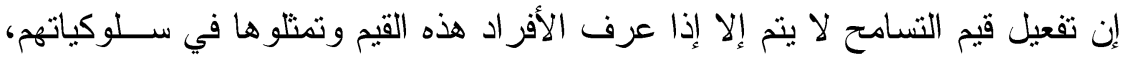

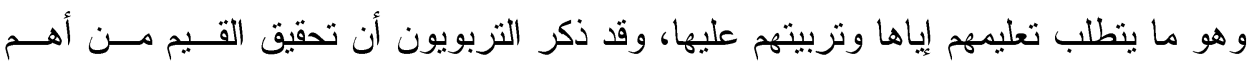
مقاصد التربية، وأن المتعلم في أية مرحلة عمرية يحتاج إلى أن يتعلم كيف ينبغي له له أن يسلك

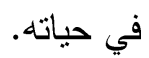
بـ التسامح من منظور بعض الفلاسفة و المربين:

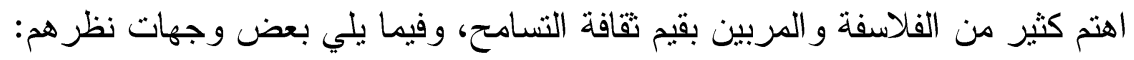

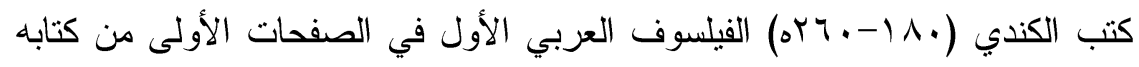

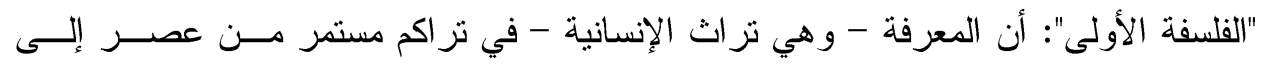

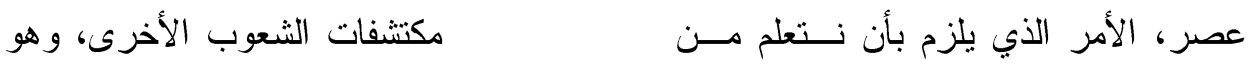


إجراعات مقترحة لتفعيل مسئولية الإدارة الجامعية نحو نشر ثقافة التسامح لاى طلابها

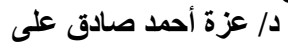

دشن أهم مقومات التسامح وهو "قبول الآخر"، الذي غاب عن أرسطو في مدينته الفاضلة.

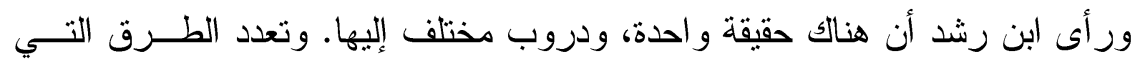

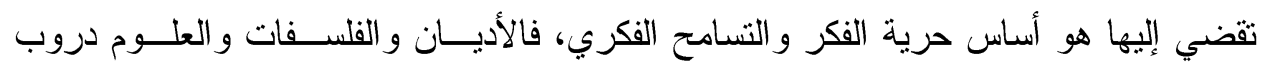

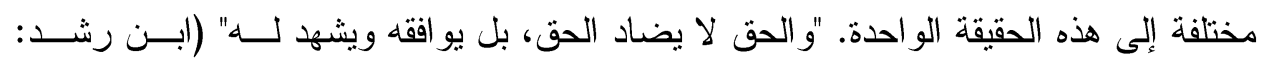

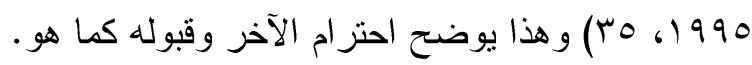

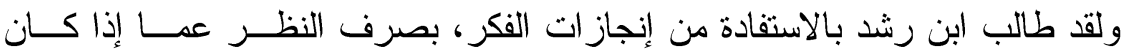

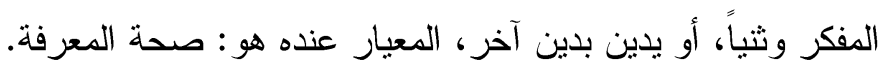

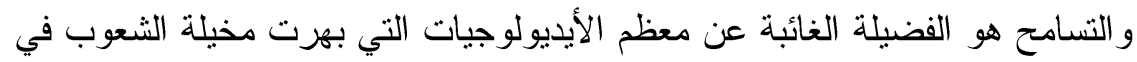

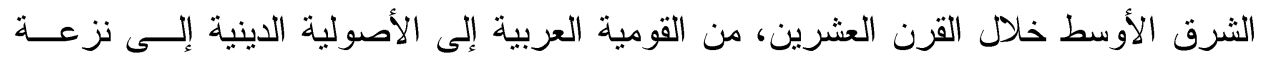
معاداة الإمبريالية، إلى الثيو عية والاثتنر اكية العربية، و الطائفية و الثعوبية.

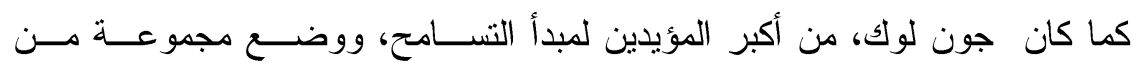

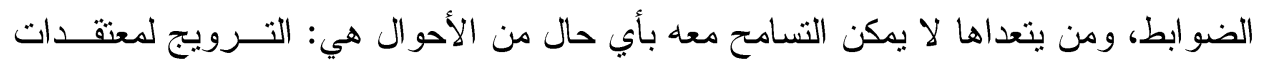

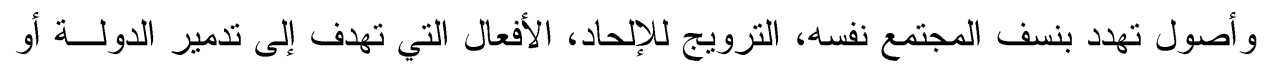

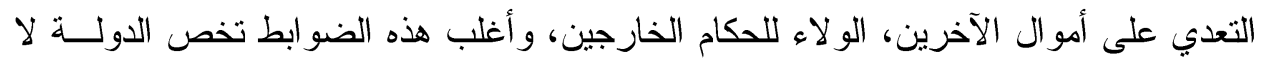

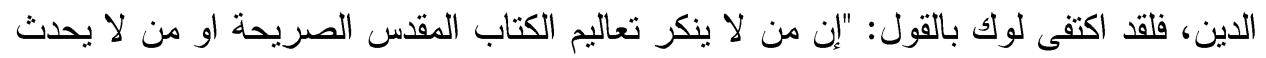

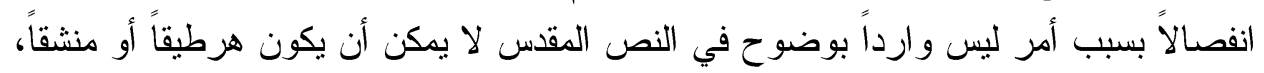

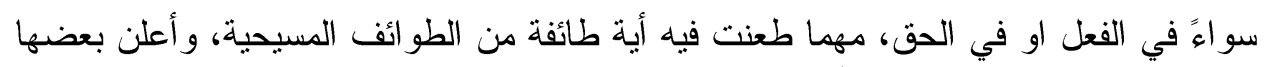

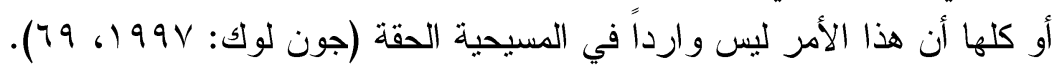

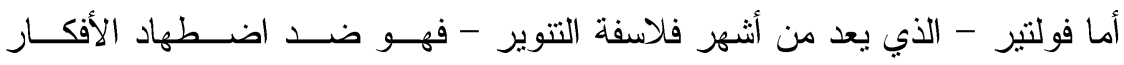

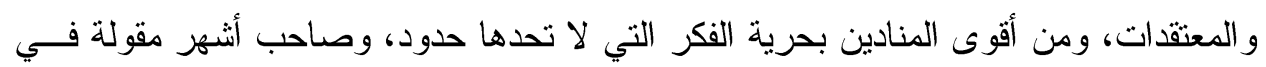

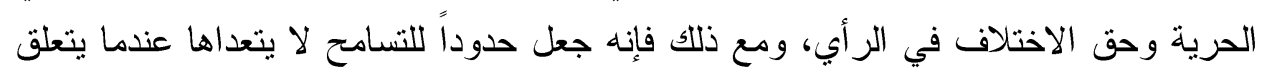

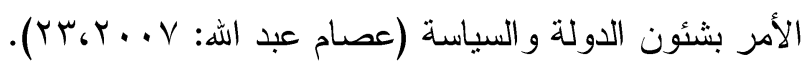

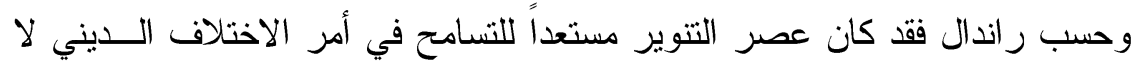

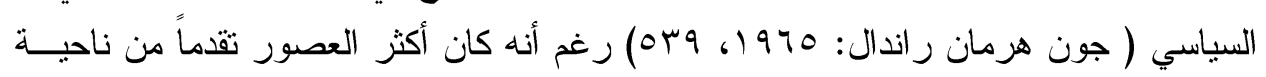
الفكر السياسي.

مما سبق يتضح أن التسامح يرتفع بالإنسان إلى مستوى الاحتر ام و المودة، فالتســامح

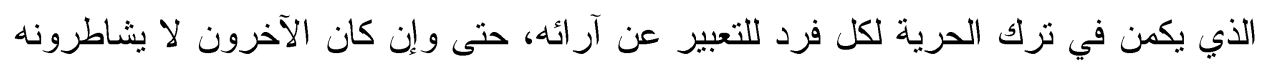

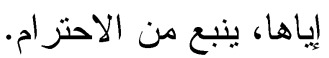
ج- التسامح من منظور إسلامي: الإسلام رسالة إلى البشرية كلها، تأمر بالعدل، وتتهى عن الظلم، وتدعو إلى التسامح، 
و التعايش بين كل الناس، والتسامح من القيم الإسلامية الرفيعة، التي تتفرد عن ســائر القـيم

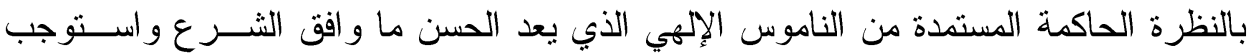

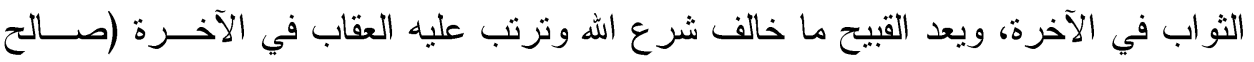

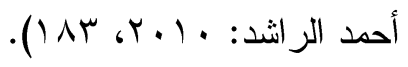

و هذه القيم تنطوي على مجموعة من القيم الأخرى، فهي إما قيم سلبية تتمثل في ترك الته

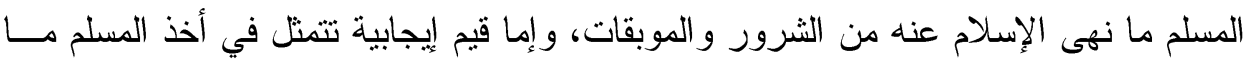

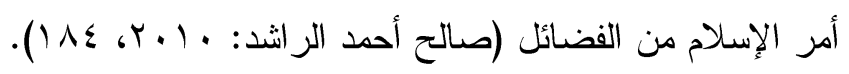

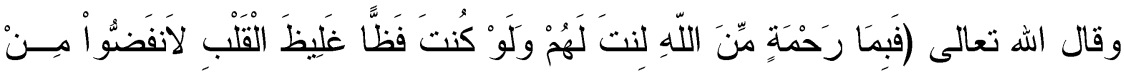

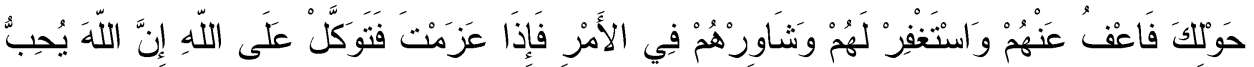

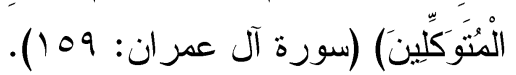

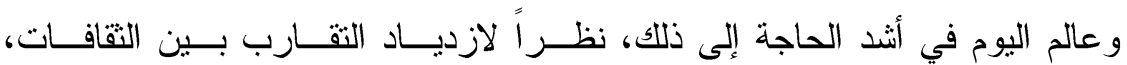

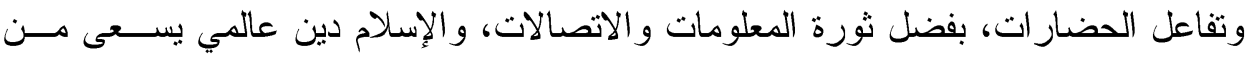

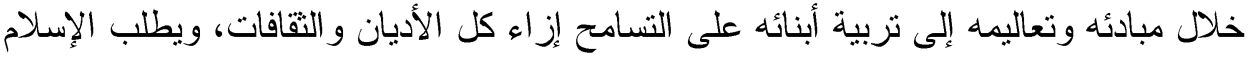

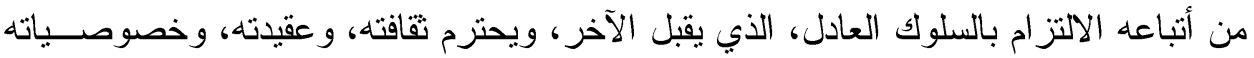

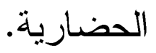

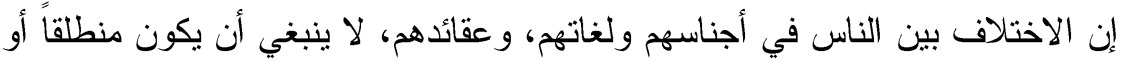

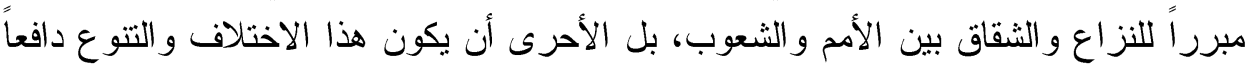

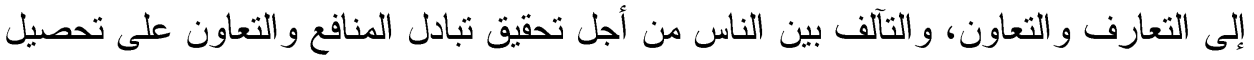

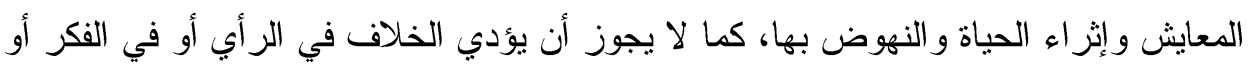
الاعتقاد إلى فساد ما بين الناس من علاقات.

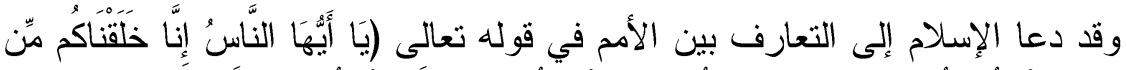

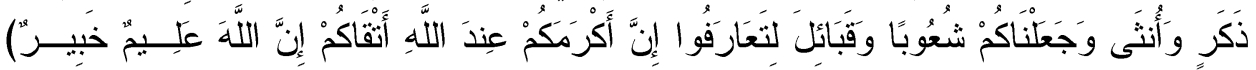

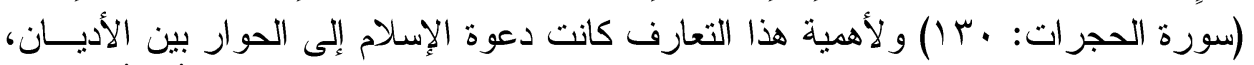

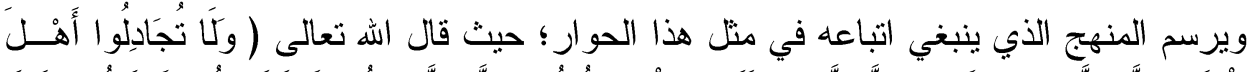

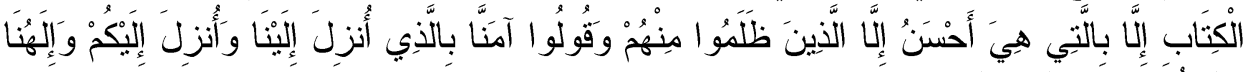

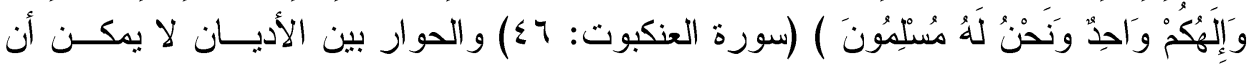

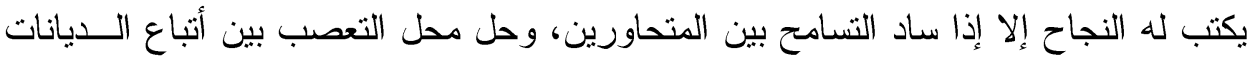
، المختلف

فالأديان السماوية جميعاً حلقات متصلة لرسالة واحدة، جاء بها الأنبياء و المرسلين مـن عنــد اله تعالى. 


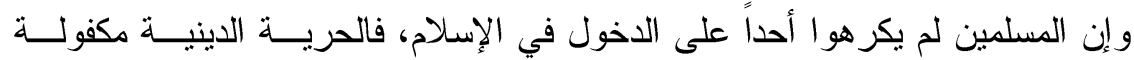

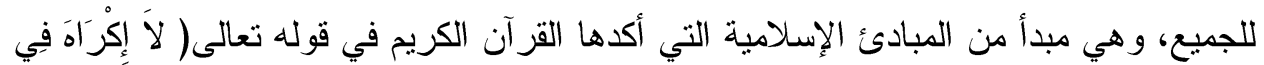

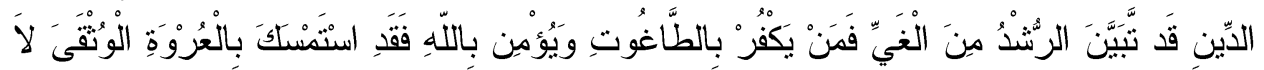

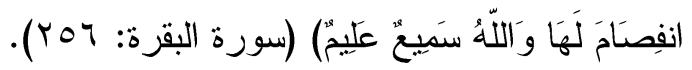

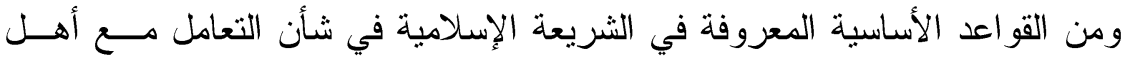

الكتاب القاعدة المعروفة: لهم ما لنا وعليه ما علينا؛ أي لهم ما لنا من حقوق وعليهم ما علينا من و اجبات، فالتز ام المسلمين بالتسامح وحمايتهم لحقوق أتباع الديانات الأخرى الذين يعيشون

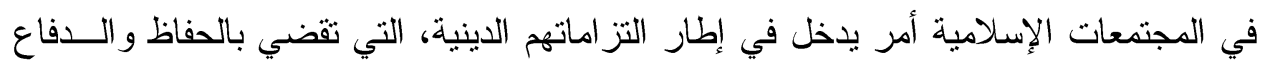

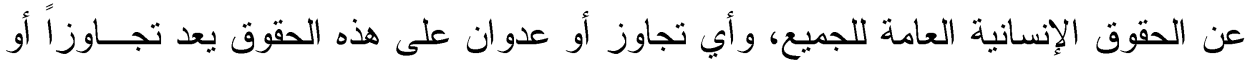

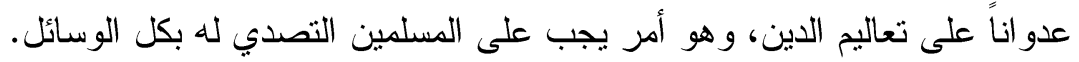

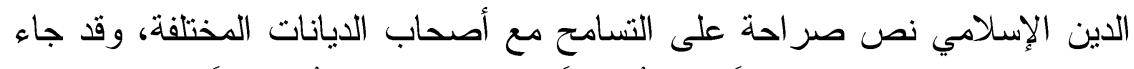

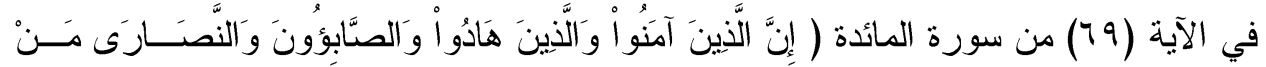

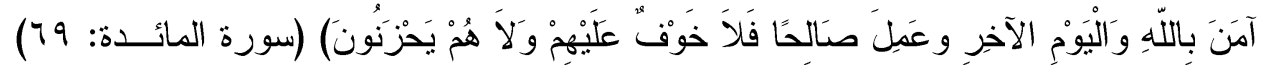

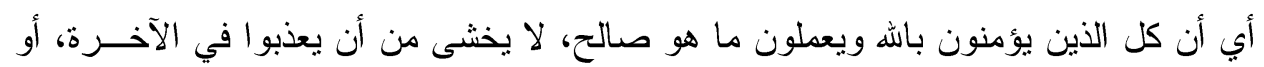

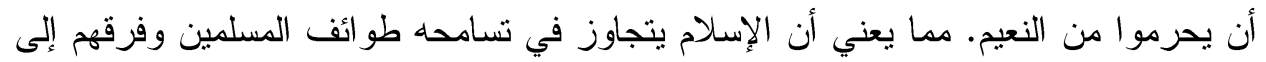

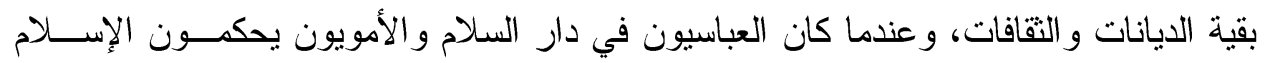

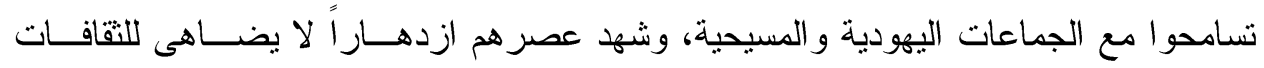
الثلاث (عصام عبد اله: V... ب، • 1-11).

إن العالم الإسلامي الواسع بموقعه المتقتح، بحضارته وتراثه، بشعوبه الحية وبوعود الماند

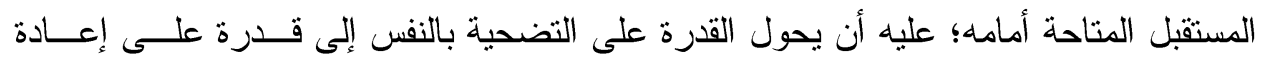

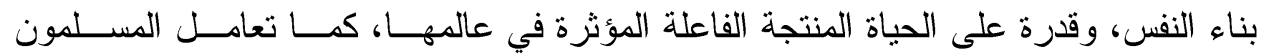

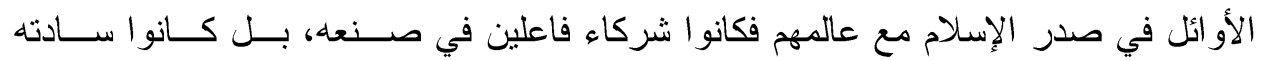

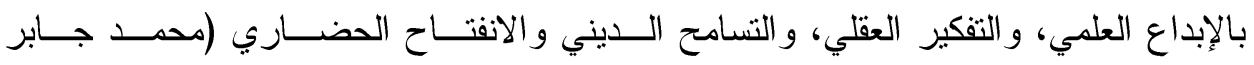

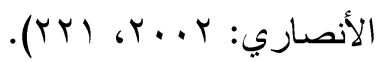

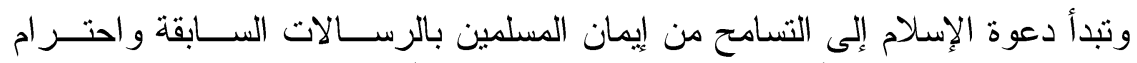

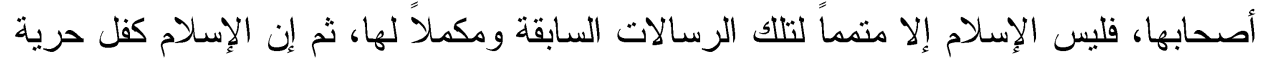

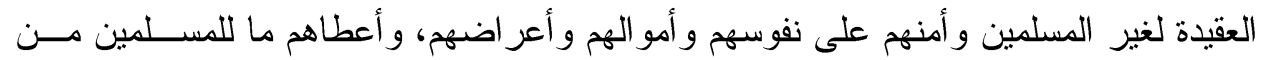

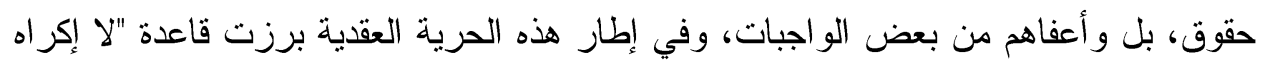
في الدين" و المجادلة بالتي هي أحسن. 


\section{ا ـ دعوة القرآن الكريم إلى التسامح:}

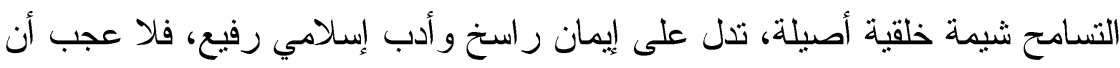

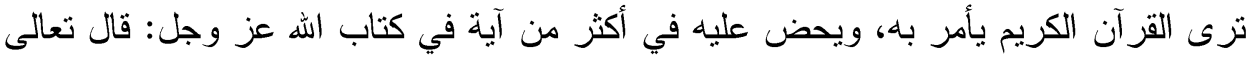

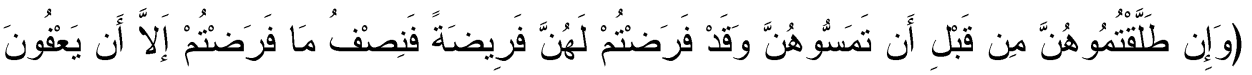

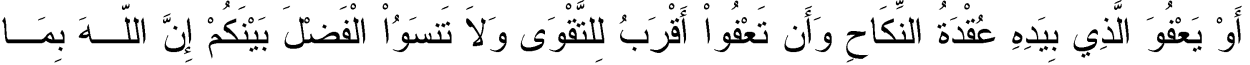

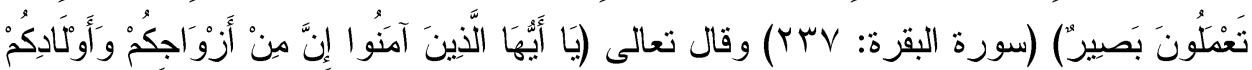

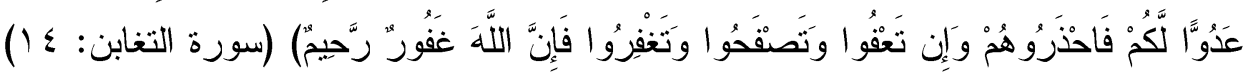

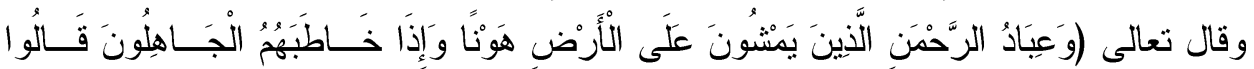

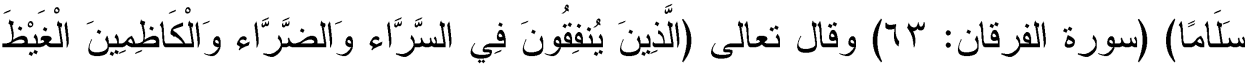

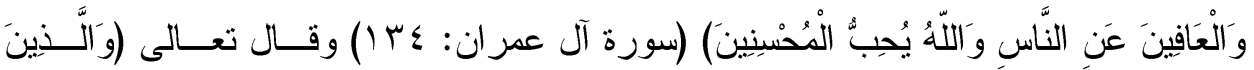

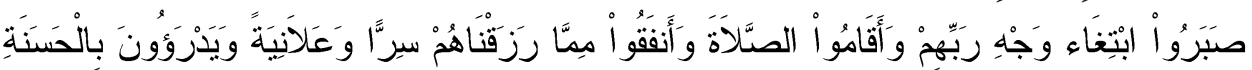

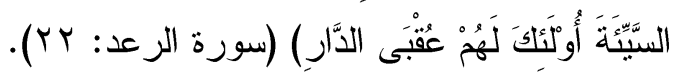

ودعا الله سبحانه وتعالى إلى مقابلة شرور الناس وإساءتهم بالإحسان إليهم، لأن ذلك الكا

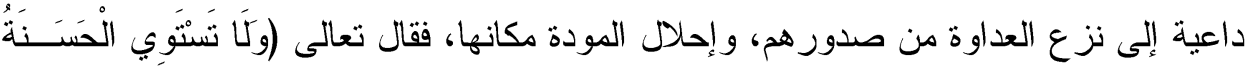

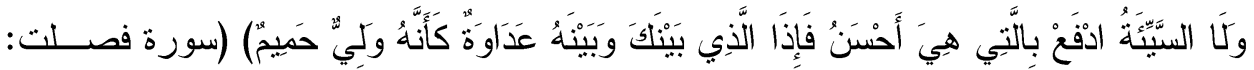

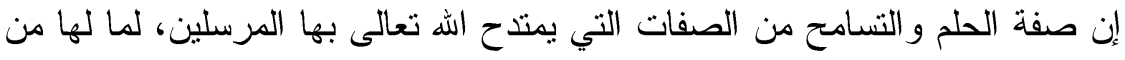
أثنز و اضح في تمكين دعوتهم، فقد وصف الله تعالى بها إبر اهيم عليه السلام بقوله (إنَّ إِبرَاهِيخم

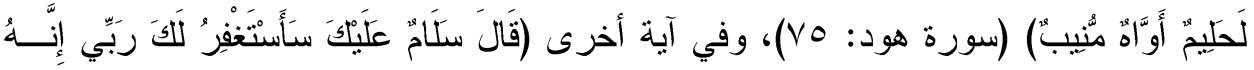

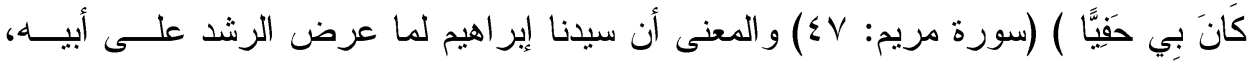
ونصحه بترك عبادة الثيطان، لم يتقبلها منه، بل تهدده وتو عده بالقطع و الهجر، قال له سـيدنا إبر اهيم " سلام عليك " أي لا يصلك من مكروه، و لا ينالك مني أذى بل أنت سالم من ناحيتي،

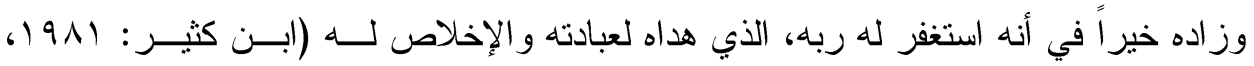

يستخلص من هذه القصة أن سيدنا إبر اهيم عليه السلام كان نسامحه مطلقاً بالنســبة

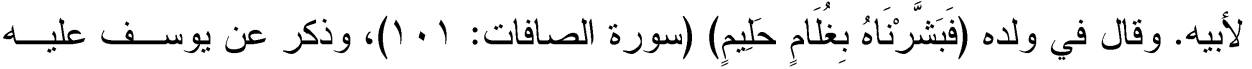

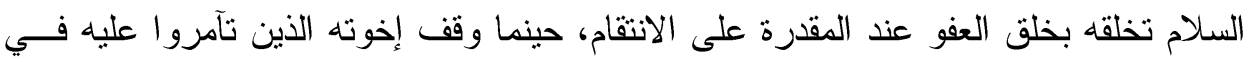

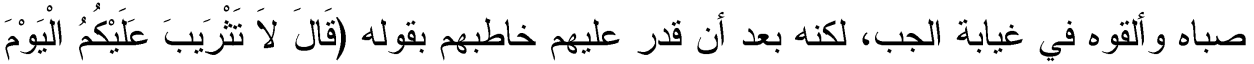




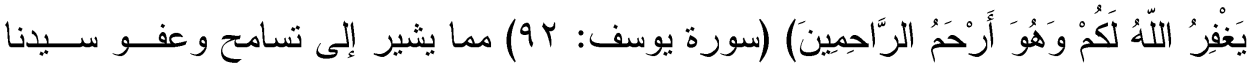
يوسف عن إخوته، وليس هذا فحسب، بل لقد دعا لهم بالمغفرة والرحمة من الله تعالى (عبـــ

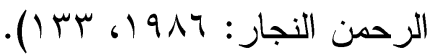
و الإسلام يجعل الأصل في الجزاء مقابلة السيئة بمثلهـــا، كـي لا يستشـري الثـــر

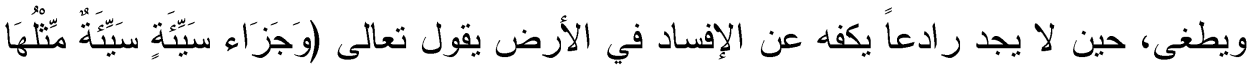

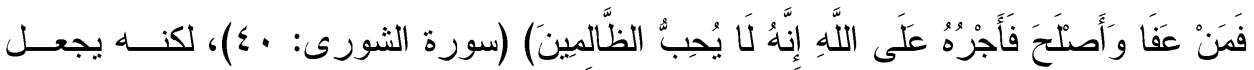
العفو و التسامح دليلاً على صلاح النفس من الغيظ، و إصلاح الجماعة من الأحقاد كما ورد في لئي الآية نفسها.

ويؤكد القرآن الكريم أن الذي ينتصر بعد ظلمه، ويجزي السيئة بالسيئة، ولا يعتدي، ليس عليه جناح وهو يزاول حقه المشروع، بدون مجاوزة للحد، ومن غير بغــي ولا ظلــم،

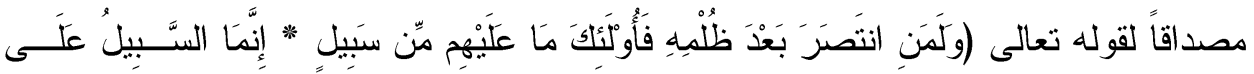

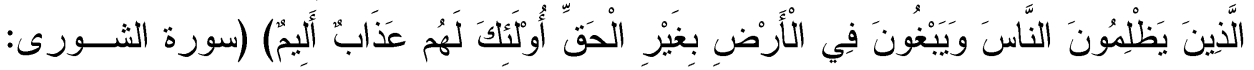

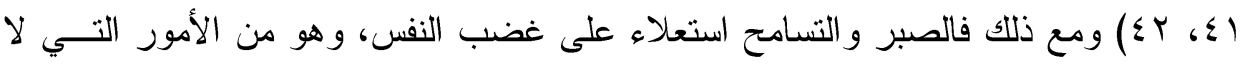

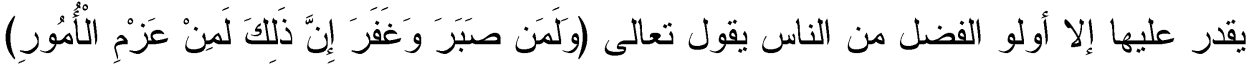

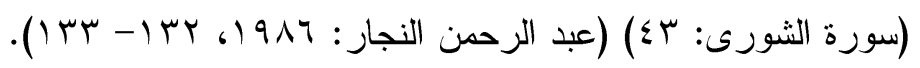

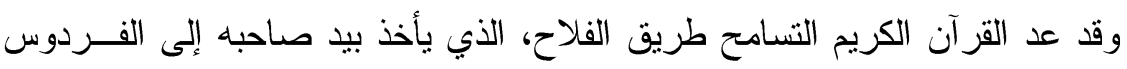

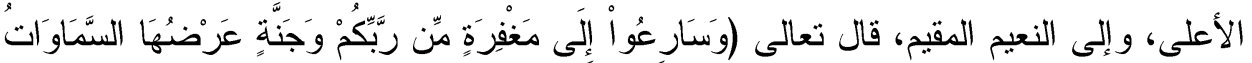

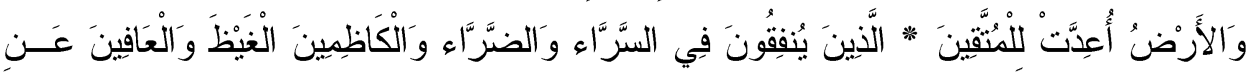

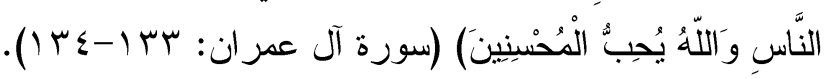
ץ ـ دعوة السنة النبوية المطهرة إلى التسامح: و الرسول صلى الله عليه وسلم الذي ألف حول دعوته القلوب، وجعل أصحابه يفدونها

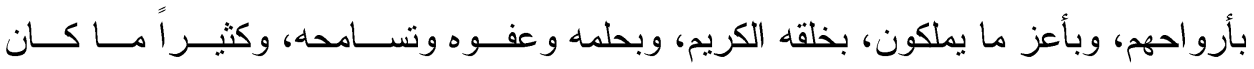
يستغضب غير أنه ما يجاوز حدود التكرم و الإغضاء، لم ينتقم لنفسه قط، إلا أن تتنهك حرمـــة

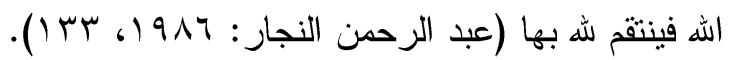

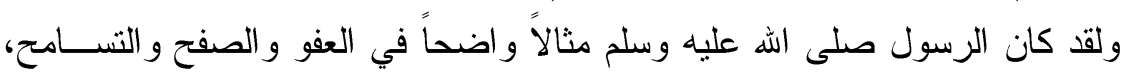
و لا عجب في ذلك فهو المبعوث رحمة للعالمين، كما أمره الله سبحانه وتعالى بذللك، فقد روي ابن جرير الطبري، و ابن أبي حاتم بسنديهما قالا: حدثا سفيان بن عيينة عن أبي قال: لما أنزل

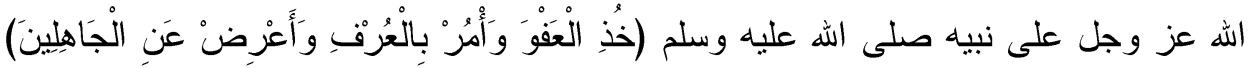
(سورة الأعراف: 99 (1)، قال الرسول صلى الله عليه وسلم: ما هذا يا جبريل؟ قال: " إن اله 
إجراءات مقترحة لتفعيل مسئولية الإدارة الجامعية نحو نثر ثقافة التسامح لاى طلابها

أمرك أن تعفو عمن ظلمك وتعطي من حرمك وتصل من قطعك " (أبي جعفر محمد بن جرير

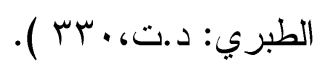

وأمثلة عفوه وصفحه وتسامحه صلى الله عليه وسلم تمتلى بها كتب الســـة النبويــة

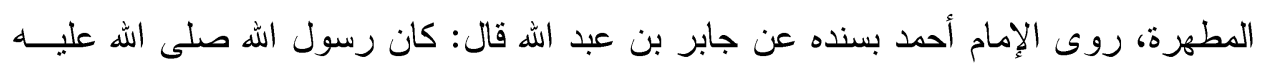

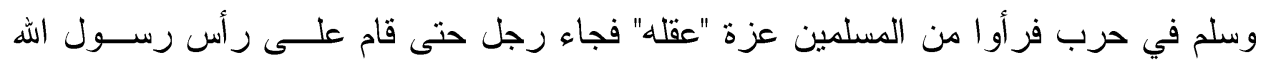
صلى الله عليه وسلم بالسيف فقال: من يمنعاك مني؟ فقال رسول الله صلى اله عليه وســلم -

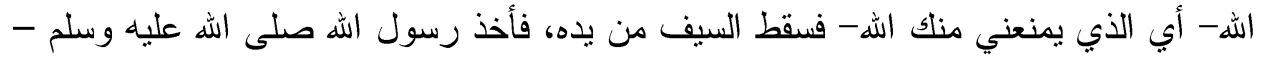

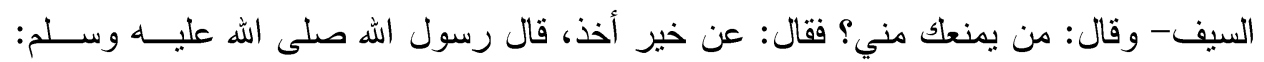

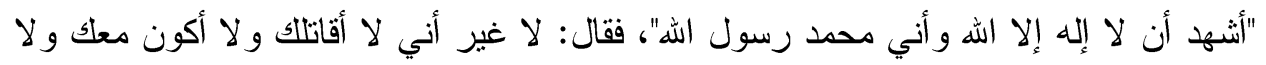

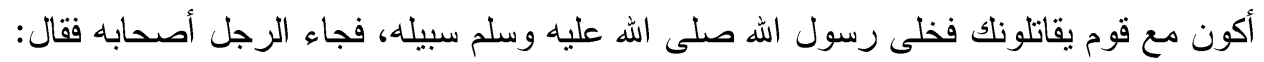

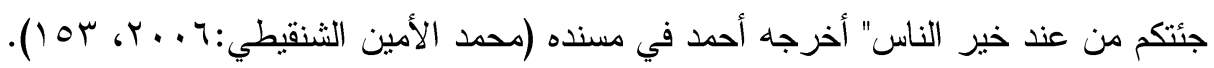

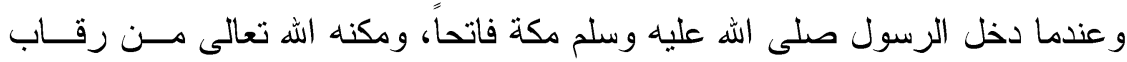

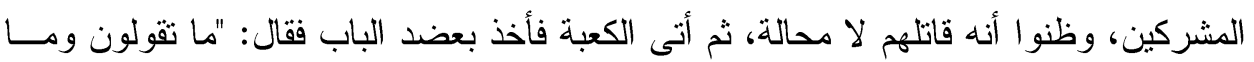

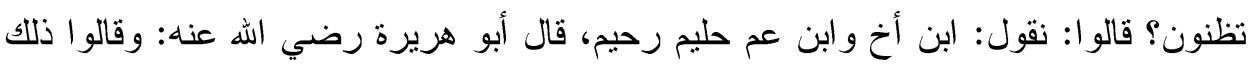

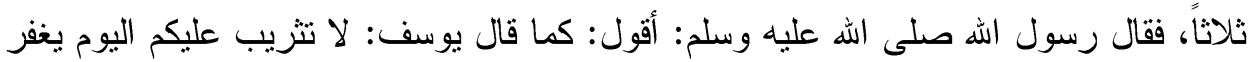

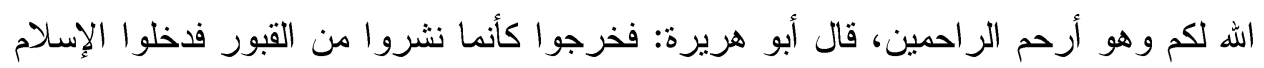

$$
\text { (أبي بكر أحمد بن الحسين بن علي البيهقي: } 1990 \text { 1)، 11) (1). }
$$

قد يخطئ أنباع الأديان ولكن ذلك لا يعني أبداً خلو الدين من التسامح، فالأديان كلها

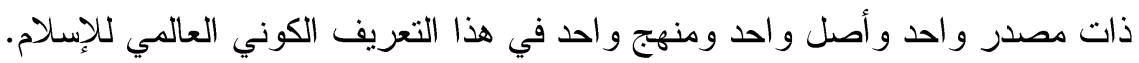

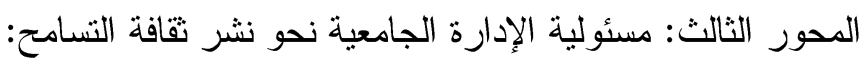
يعد الثباب قطاعًا محوريًا في المجتمع، ليس فئَة منعزلة معرفياً أو قيمياً او اجتماعياً

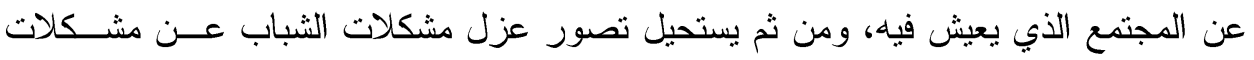

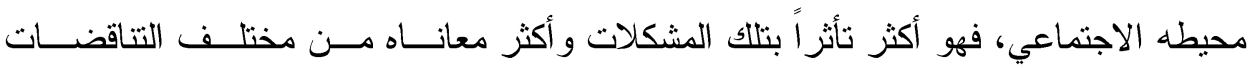

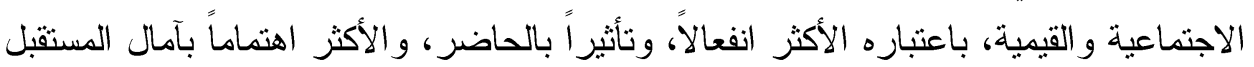

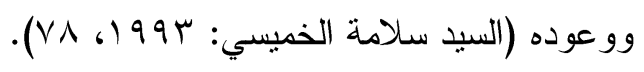

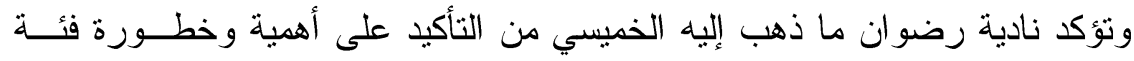

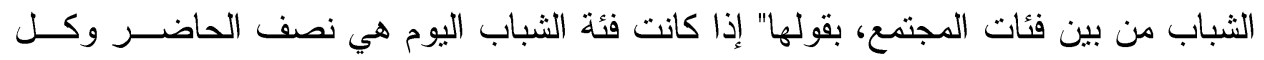

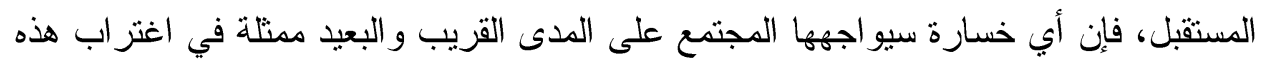

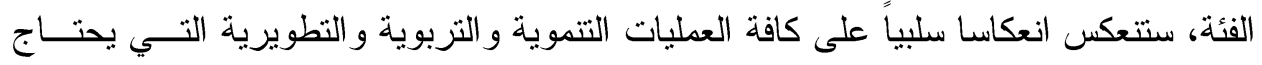

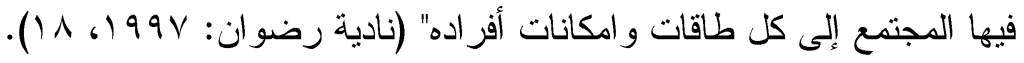


إجراءات مقترحة لتفعيل مسئولية الإدارة الجامعية نحو نثر ثقافة التسامح لاى طلابها

و انطلاقاً من أهمية الجامعات كمحاضن لهذه الفئة الهامــة فــي التكــوين العلمــي

و المعرفي و المهارى و القيمي للطلاب وتكوين شخصياتهم ونسقهم القيمي لابد للجامعسـة مسنـ الوقوف على مسئوليتها في تعميق القيم الفاضلة لدى طلابها، و التركيز على ثقافــة التســامح بشكل خاص في ضوء معطيات و احتياجات الوضع الاجتماعي و السياسي المصري الــر اهن،

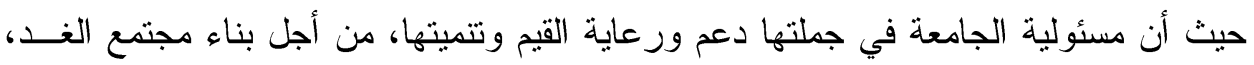
و أن تعمل على تحقيق الارنباط الوثيق بين الطالب و المجتمع وتتمية وعيه بالقضايا و المشكلات

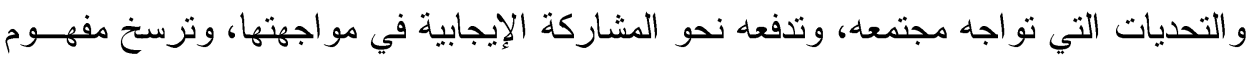
الجامعة في خدمة المجتمع

كما ينبغي على الجامعة أن تز اعي حاجات وخصائص الثباب الجامعي، بالإضــافة

إلى تقديم الحالة الخاصة للظروف السياسية التي يعيشها الثعب المصري ومتطلباتها وتبعاتهــا لإنا التقيلة لاسيما على قطاع الثباب الجامعي وبالتالي لابد أن تقوم الجامعة بتتوير عقولهم وتعزيز تقتهم بأنفسهم، وتتمية مشاعر الفخر والاعتزاز بهم وبالوطن، وكذلك تعزيز مشاعر الانتمــاء

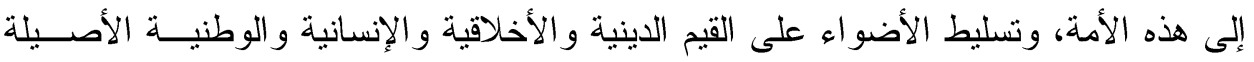

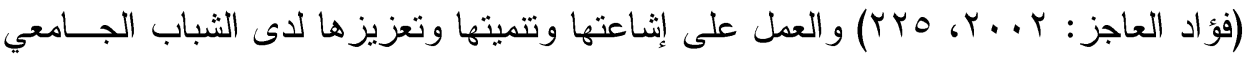
من خلال تهيئة بيئة جامعية ومناخ اجتماعي ووطني و إنساني يسوده الحب و الانتماء و التسامح

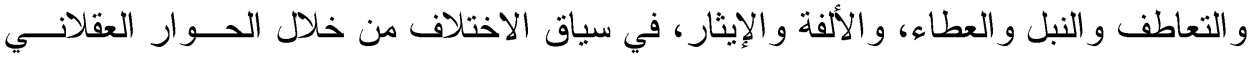

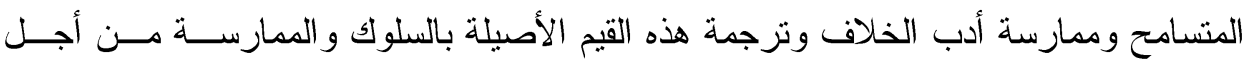
تجسيد القدوة و المثل في أساتذة الجامعات بشكل عام، وفي إدارتها التزبوية بشكل خاص. ولكي تتمكن الجامعة من تعميق ونشر ثقافة التسامح لدى طلابها، بما يؤهلهم للتعامل

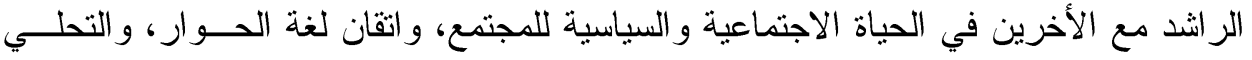

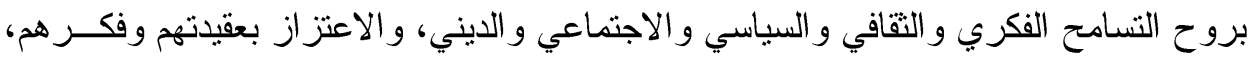

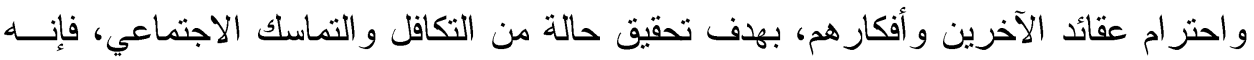
يتعين على الجامعة إحداث تغييرات وتعديلات جوهرية في المناخ العلمي و الفكـري والإداري

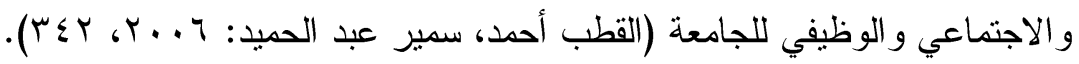

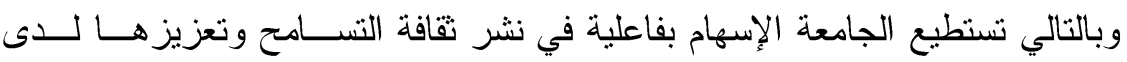
طلابها، من خلال إحداث تغييرات جوهرية في النمط الإداري الذي يمارس داخل الجامعــة، حيث أن هذا النمط هو المسئول عن توفير المناخ الإنساني والاجتماعي الذي يعلي مــن قــدر

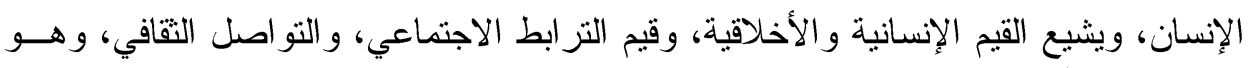

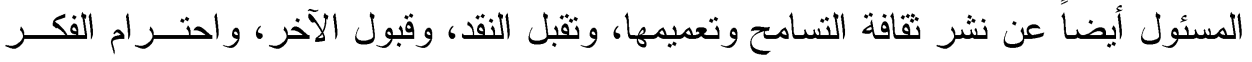

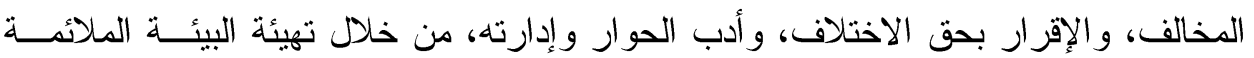
داخل الحرم الجامعي (محمد حسن محمد المزين:9 . . . ب، 9. 9). 
إجراءات مقترحة لتفعيل مسئولية الإدارة الجامعية نحو نثر ثقافة التسامح لاى طلابها

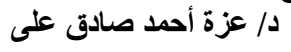

ولكي تستطيع الإدارة الجامعية القيام بمسئوليتها في نشر نقافة التسامح- لاسيما فــي

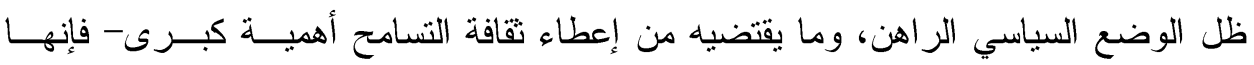
تسنطيع القيام بذلك من خلال مجموعة من الآليات الآتية:

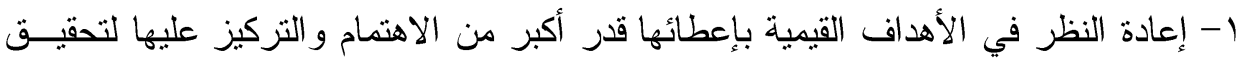

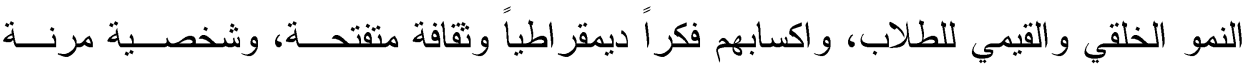
منسامحة، تمكنهر من مو اكبة التغير ات في المجتمع، وتأدية دور إيجابي فيه.

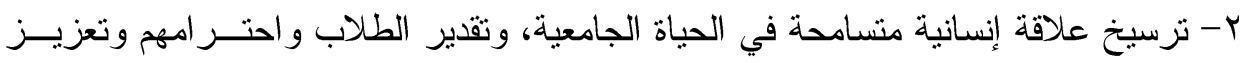

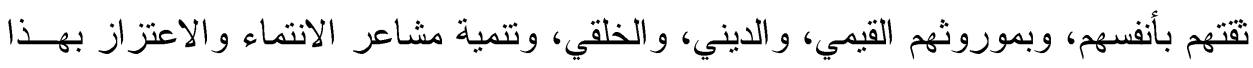

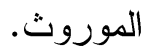

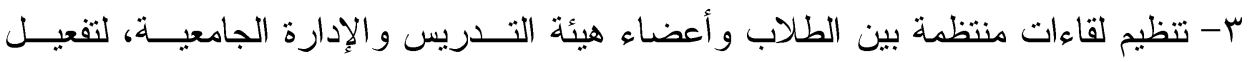

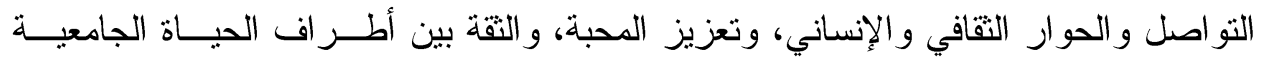

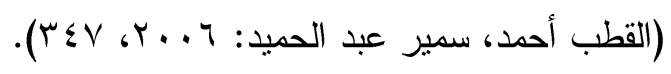

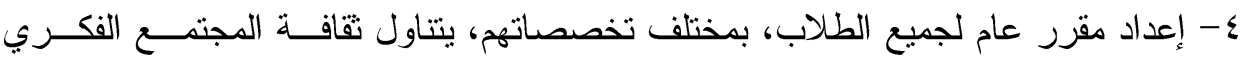

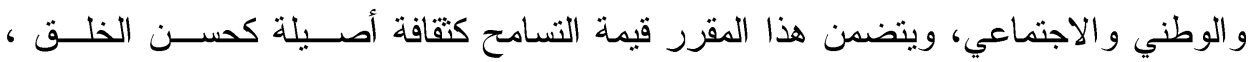

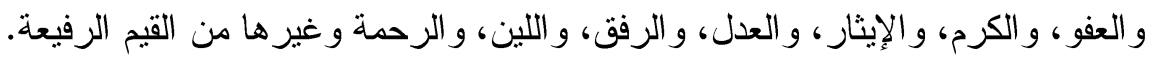

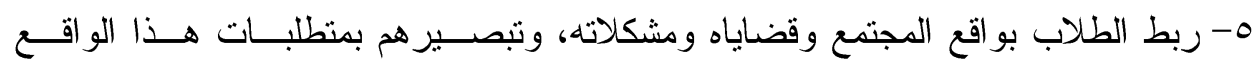

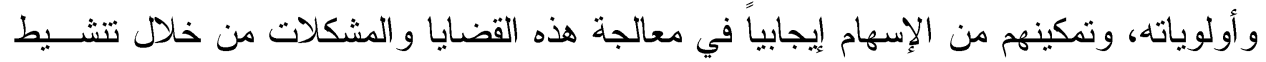

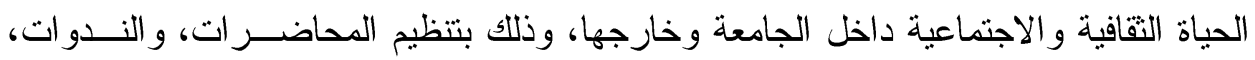
و المؤتمرات وورش العمل، والمشاركة في مختلف الفعاليات ذات الصلة بقضايا الر أب العام.

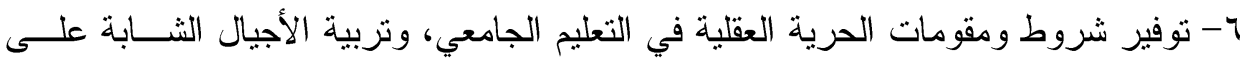

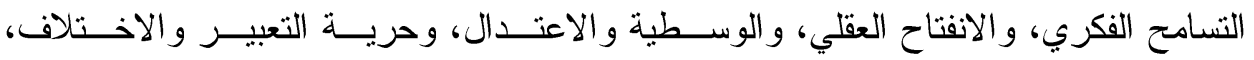

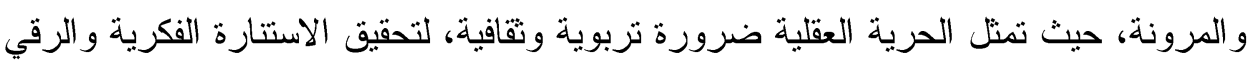

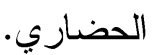

V- العمل في ظل مناخ إداري مفتوح يسمح بتوسيع دائرة المشاركة في اتخاذ القرار ، ويعطي

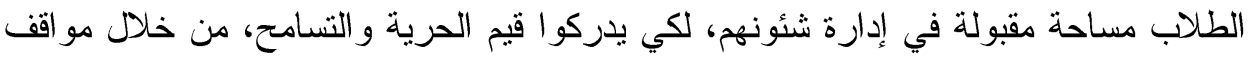

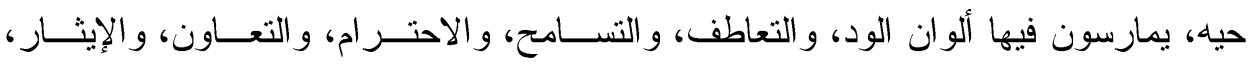
و المشاركة الإيجابية.

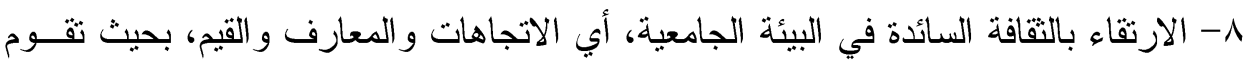

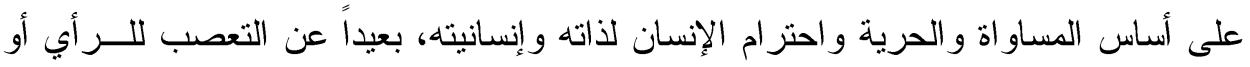


إجراعات مقترحة لتفعيل مسئولية الإدارة الجامعية نحو نشر ثقافة التسامح لاى طلابها

التطرف في الاتجاه و الاعتقاد، وتوفر مناخ مـن الحريــة، والأمسـن، و التنـــامح، و العدالــة

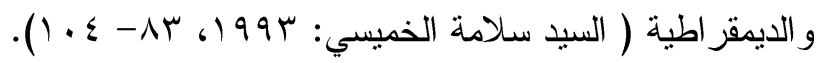

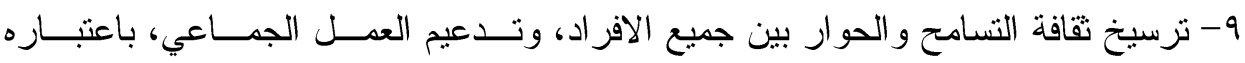
الأساس داخل الجامعة.

• 1- الالتز ام الكامل من قبل الإدارة الجامعية بنمط قيادي ديمقر اطي منسامح. 1)

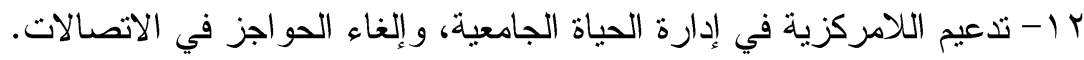

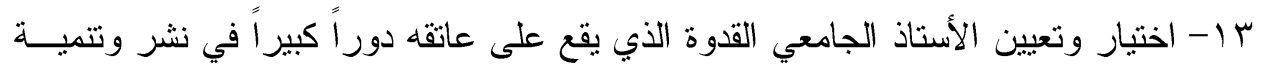
ثقافة التسامح لدى طلابه.

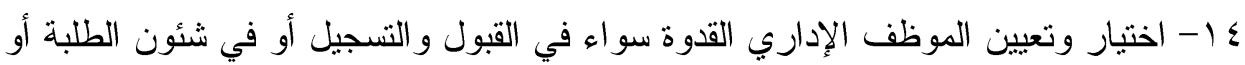

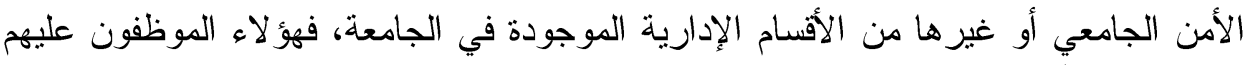

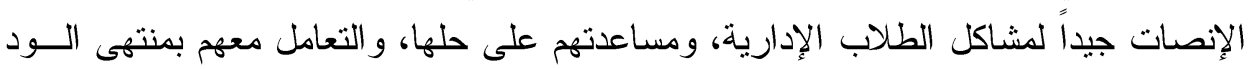

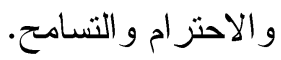

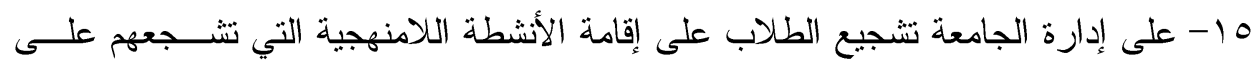
ابداء آر اءهم في الموضو عات، التي تهمهم كثباب دون المساس بسياسة الجامعة.

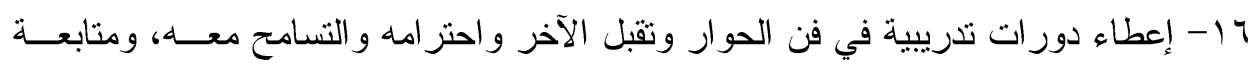

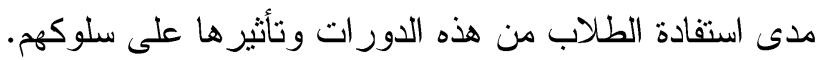

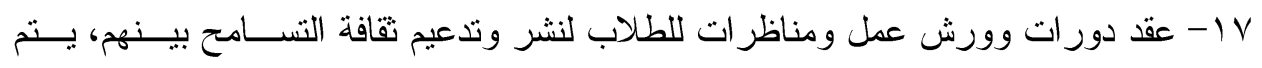
إدارتها بشكل حضاري وو اعي. 1 1- تعميم ونشر مطويات توزع على الطلاب يتم الحديث فيها عن ثقافة الحوار و التســامح،

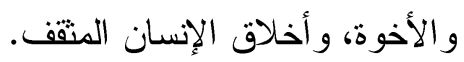

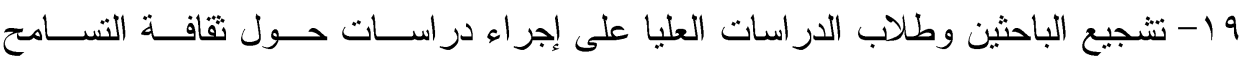
و أهميتها و آليات نشر ها وتتميتها.

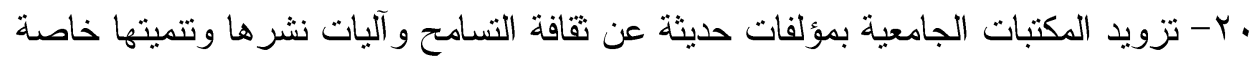
في ظل ندرة الكتب التي تتحدث عن هذه الثقافة.

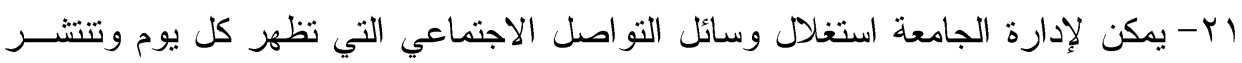
بسرعة بين فئة الثباب- خاصة طلاب الجامعات منهم- وعمل صفحات لنشر نقافة التســامح تكون تابعة لإدارة الجامعة. المحور الر ابع: نتائج البحث و الإجر اءات المقترحة والتوصيات و البحوث المقترحة: 
إجراءات مقترحة لتفعيل مسئولية الإدارة الجامعية نحو نثر ثقافة التسامح لاى طلابها

يعرض البحث في هذا المحور نتائجه و الإجر اءات المقترحة و التوصيات و البحــوث

$$
\begin{aligned}
& \text { المقترحة، كما هي موضحة في الآتي: } \\
& \text { أولاً: نتائج البحث: البيث: }
\end{aligned}
$$

أسفر البحث الحالي عن مجموعة من النتائج يمكن تتاولها فيما يأتي:

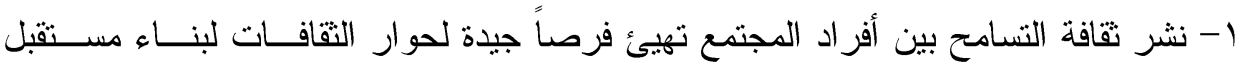

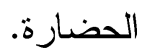

ب- ثقافة التسامح لا تكون ثقافة إلا بقدر رسوخها كتقافة أخلاقية تسوس الناس وتصدر عنهـــا

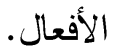

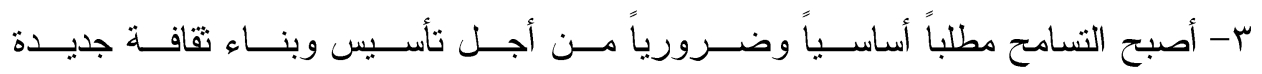

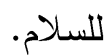
ع- ثقافة التسامح أصبحت ضرورة بل و أمر اً مرغوباً فيه بين الأفراد، وعلى صــعيد كافــة

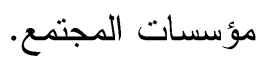
ه- ثقافة التسامح تسمح بالتتوع الفكري و العقائدي.

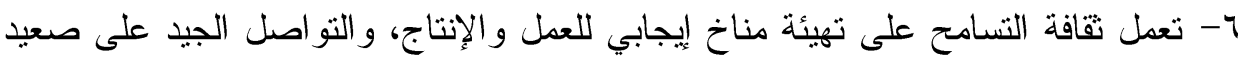
علاقات العمل، أو على مستوى العلاقات الدولية.

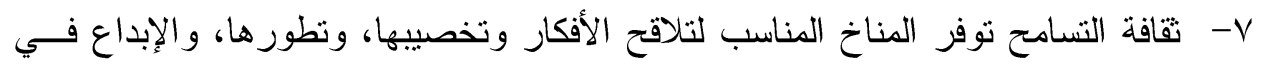

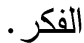
^- ثقافة التسامح تقيم في حياة الإنسان قسطاً كبيراً من محبة الناس وتقتهم فيـه، وتعــاطفهم معله

9- التزبية كعملية اجتماعية هادفة؛ يمكن أن نسهم في توفير الثــروط الملائمــة لعلاقــات يسودها التسامح. • 1- التسامح الإيجابي بوصفه تسامحاً شاملاً أو تسامحاً دينياً من العناصر الأساسية في تعاليم الإسلام، ومن أهداف التزبية الإسلامية.

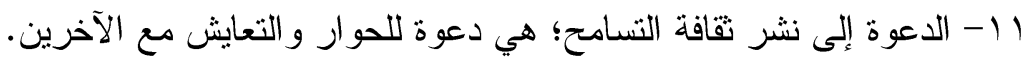

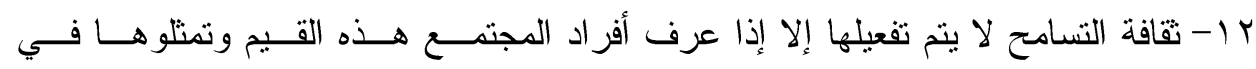
سلوكياتهم. rا - لكي يتجسد التسامح في فكر وثقافة الأجيال، لابد أن تسهم كل مؤسسات المجتمع، وفئاته وفي مقدمتها مؤسسات التعليم في نشر فكر التسامح، وترسيخ نقافته.

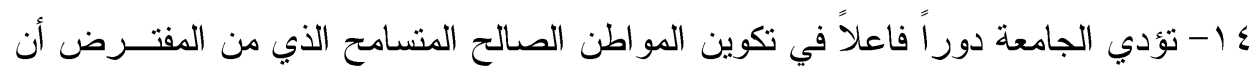


إجراعات مقترحة لتفعيل مسئولية الإدارة الجامعية نحو نشر ثقافة التسامح لاى طلابها

تتميز شخصيته بالسلوك الأخلاقي، الذي توجهه القيم و المبادئ الأخلاقية.

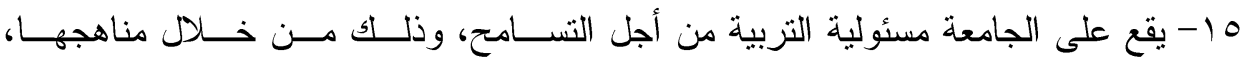
وفاعلياتها، و أنظمتها، ولو ائحها الإدارية.

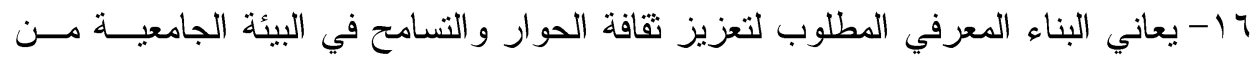
نقص شديد. V ا الطلاب في الجامعات العربية لا بملكون معرفة كافية بمقومات الحوار، ومهار اته، فضلاً

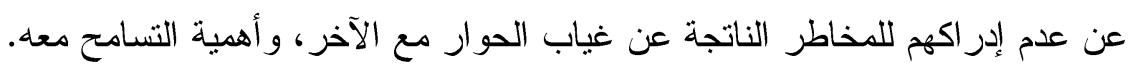

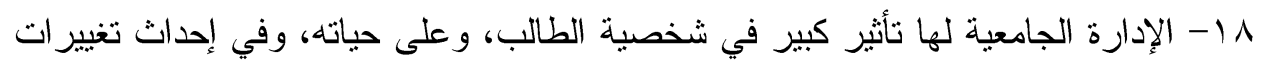
في قيم، و أفكار، ومعتقدات الثباب الجامعي، من خلال اهتمامها بنشر ثقافة التشامح.

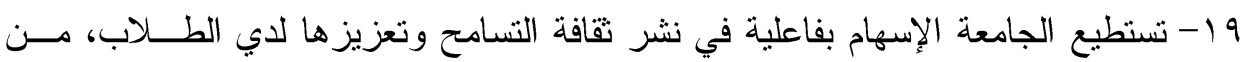
خلال إحداث تغييرات جوهرية في النمط الإداري الذي يمارس داخل الجامعة.

ثانيـاً: الإجـر اءات المقترحـة لتفعيـل مسـئولية الإدارة الجامعيـة نحـو نشـر تقافة التسامح لانى طلابها: في ضوء ما أسفرت عنه الدراسة النظرية التي أثشارت إلى أهمية ثقافة التنــامح،

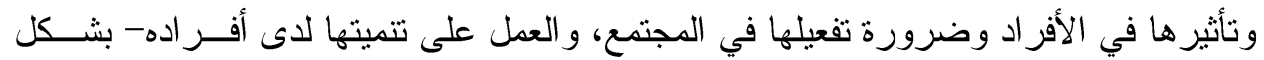

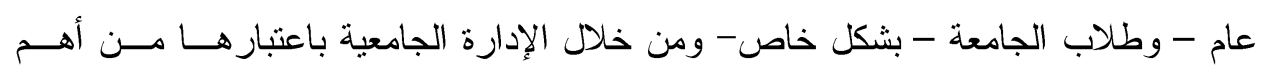
مقومات الجامعة في نشر نقافة التسامح، ومن أن التسامح يمثل قدرة الأفراد و الدول على إلى إبداء

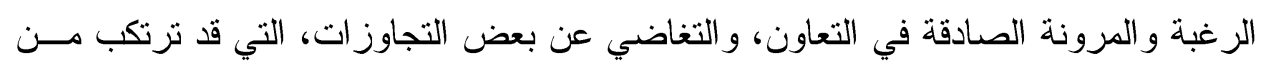

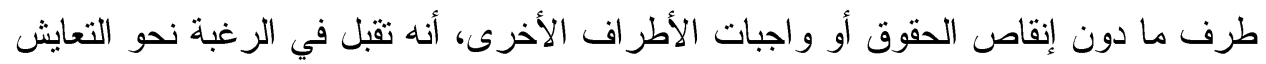

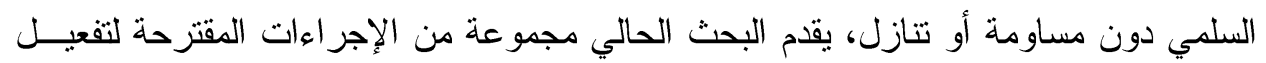
مسئولية الإدارة الجامعية نحو نشر نقافة التسامح لدى طلابها، وذللك على النحو الآتي:

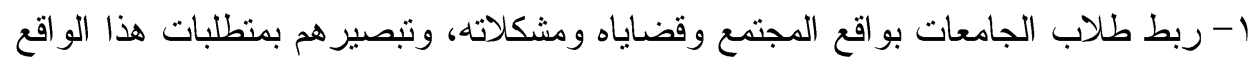
وأولوياته، وتمكينهم من الإسهام إيجابياً في معالجة هذه القضايا و المشكلات.

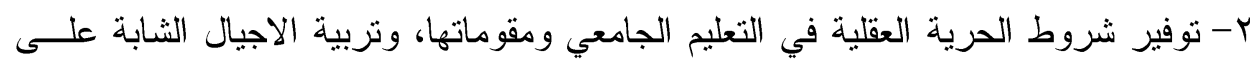

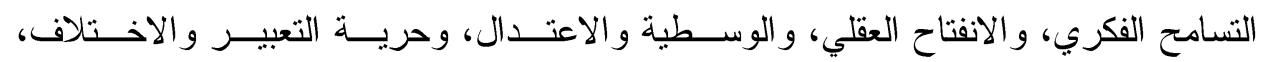

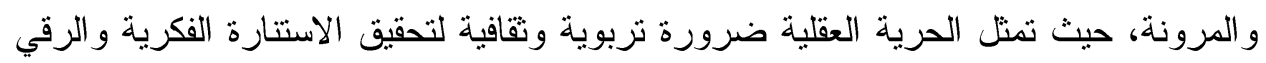
الحضاري. 
إجراءات مقترحة لتفعيل مسئولية الإدارة الجامعية نحو نثر ثقافة التسامح لاى طلابها

س- العمل في ظل مناخ إداري جامعي مفتوح يسمح بتوسيع دائرة المشاركة في اتخاذ القرار،

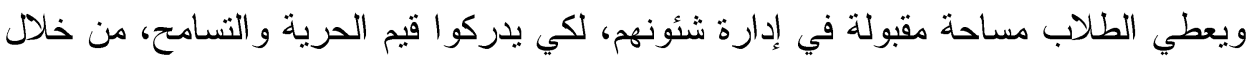

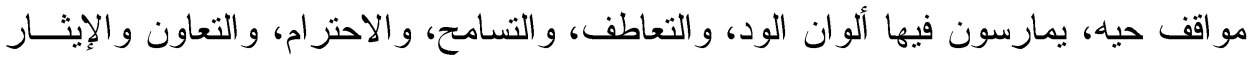
و المشاركة الإيجابية.

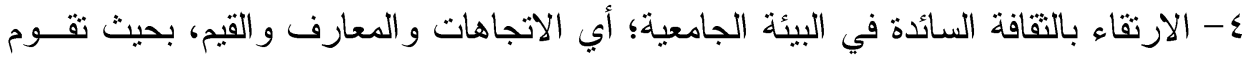

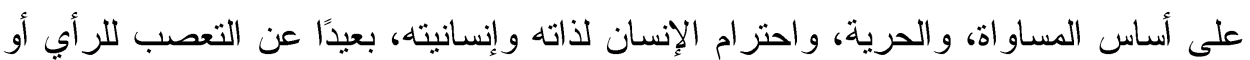

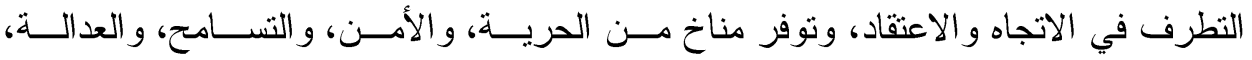

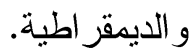
0- ترسيخ ثقافة التسامح و الحوار بين جميع الافراد، وتــــعيم العهـل الجمــــي، باعتبــاره

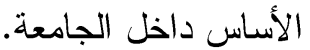
؟- الالتز ام الكامل من قبل الإدارة الجامعية بنمط قيادي ديمقر اطي متسامح.

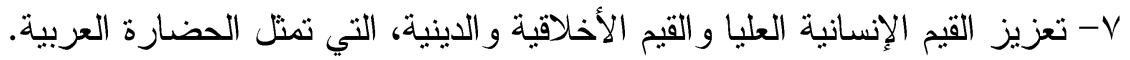

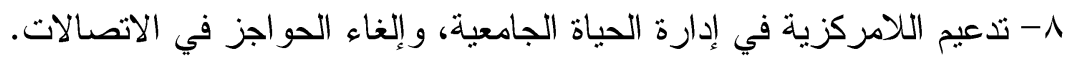

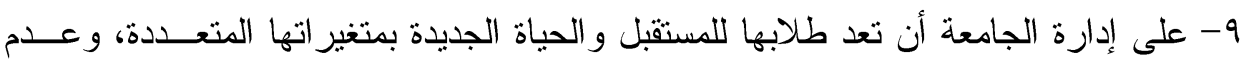

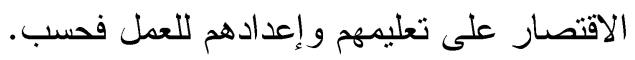

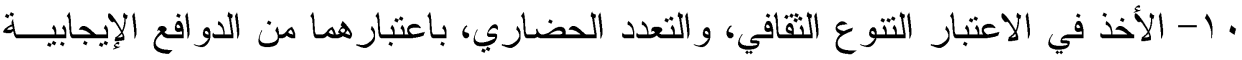

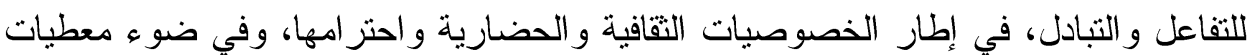

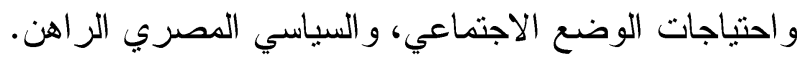

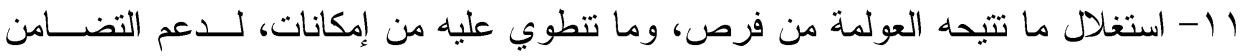
و التعاون و العيش المشترك بين الثعوب. r إ - إعادة النظر في الأهداف القيمية بإعطائها قدرًا أكبر من الاهتمام و التركيز عليها، لتحقيق النمو الخلقي و القيمي للطلاب. بr إ-ترسيخ علاقة إنسانية متسامحة في الحياة الجامعية، وتقدير الطلاب، و احتر امهم، وتعزيز تقتهم بأنفسهم، وبموروثهم القيمي، و الديني، و الخلقي.

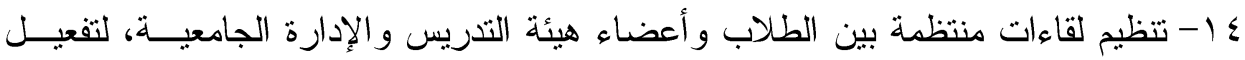
التو اصل و الحوار التقافي و الإنساني. 10 - إعداد مقرر عام لجميع الطلاب يتضمن منظومة من قيم التسامح الأصيلة.

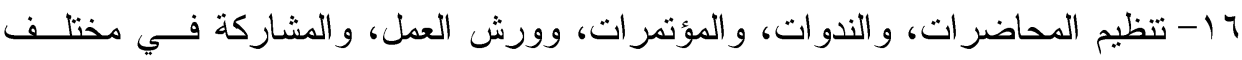

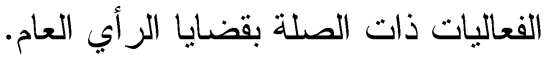
IV 
إجراعات مقترحة لتفعيل مسئولية الإدارة الجامعية نحو نشر ثقافة التسامح لاى طلابها

1 ا- اختيار وتعيين الموظف الإداري القدوة في الحوار و الاحترام و التنسامح.

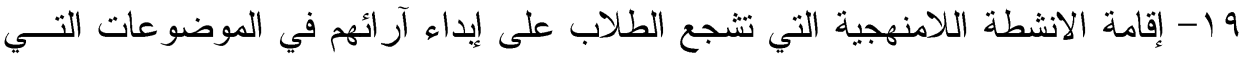
تههم كشباب دون المساس بسياسة الجامعة. • r- إعطاء دورات تدريبية في فن الحوار وتقبل الآخر و احتر امه و التسامح معــه، ومتابعــة

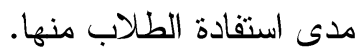

اYY- عقد دورات وورش عمل ومناظرات للطلاب يتم إدارتها بشكل حضاري وو اعي.

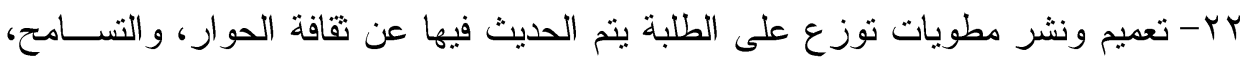

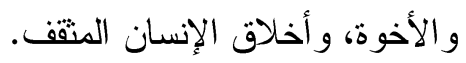

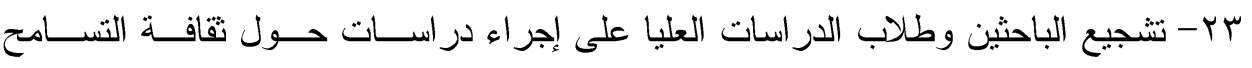

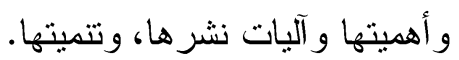

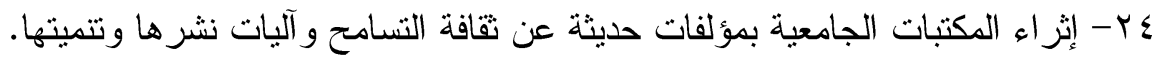
0Y - عمل صفحات على مو اقع التواصل الاجتماعي لنشر تقافة التسامح تكون تابعــة لإدارة

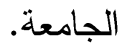

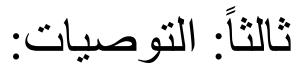
في ضوء ما توصل البحث إليه من نتائج، ومن تقديمه لمجموعة مــن الإجــراءات

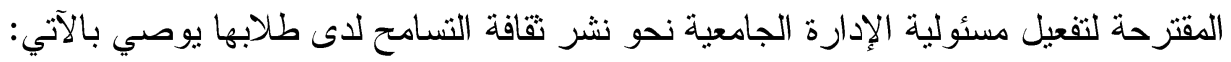

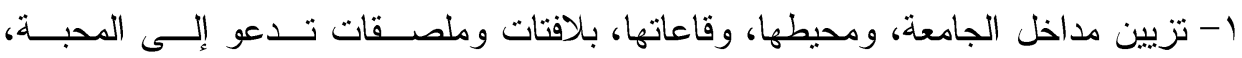
و التسامح، و الوحدة، و الوئام. ب- الإعداد لمؤتمر وطني تسامحي تشارك في إعداده، وتتفيــذه، ورعايتــهـ كـلـل الجامعـات المصرية، بهدف الوحدة و التماسك.

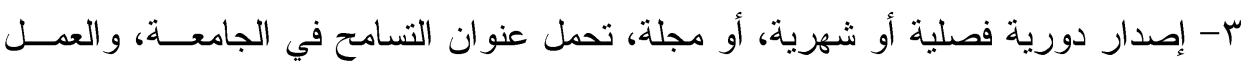
على نشرها عبر شبكة الإنترنت على موقع الجامعة.

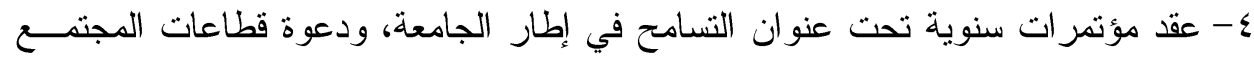
للمشاركة فيها و الإفادة منها، بهدف نشر ثقافة التسامح في المجتمع.

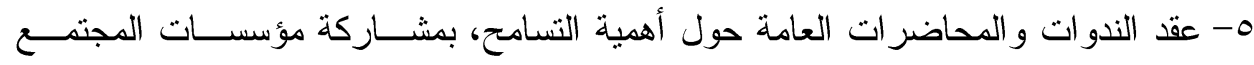
المدني. צ- عقد ورش عمل، ودورات تدريبية للمحاضرين في الجامعة، لتدرييهم على آليـات نشــر

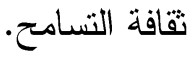
V- تتفيذ بر امج إرشادية لتنمية التسامح بين الطلاب، لاسيما ممن يحملون أفكارًا متعصبة. 
1- ترسيخ ثقافة التسامح في المناهج، والخطط الدر اسية، مع التركيز على الجانب التطبيقي. 9- أن تتيح إدارة الجامعة لكافة التتظيمات السياسية الفرص لممارسة نشاطاتها الحزبية داخل

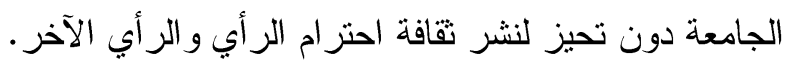

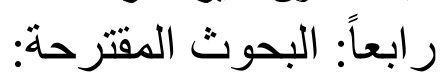
يقترح البحث الحالي تكملة مسيرته من خلال القيام بإجر اء البحوث و الدراسات في

$$
\text { المجالات الآتية: - المات }
$$

1- منطلبات تفعيل دور الجامعة في نشر تقافة التسامح.

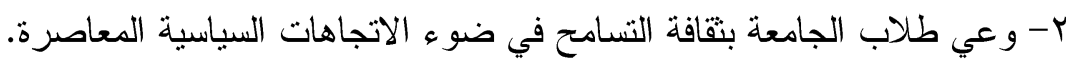
ب- دور مؤسسات المجتمع المدني في نشر ثقافة التسامح لدى الخريجين. ع- إجر اء دراسات تتعلق بدور أعضاء هيئة التدريس، و الأشططة الطلابية، و المناهج الدراسية، و المكتبات، في نشر نقافة التنسامح. 
ب- ابن رشد (1990): فصل المقال فيما بين الحكمة والثربعة من اتصال، تحقيـقن: البيـر

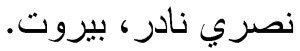

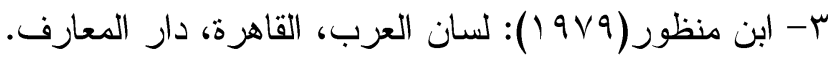

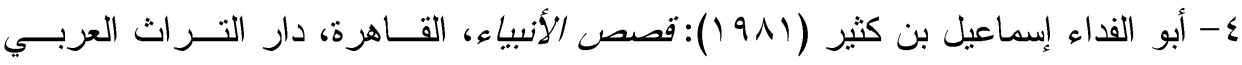
للطباعة و النشر.

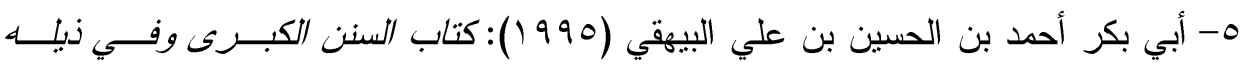
الجوهر النقي، ج9، لبنان، بيروت، دار المعرفة.

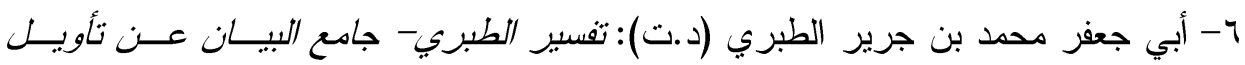
القرآن، جبا ا، القاهرة، مكتبة ابن تيمية.

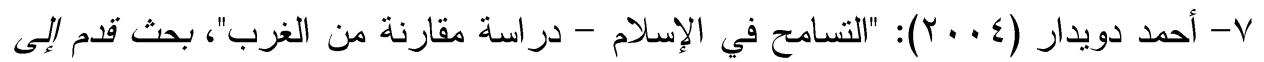

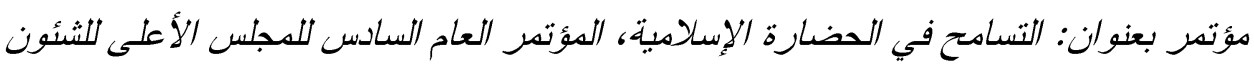

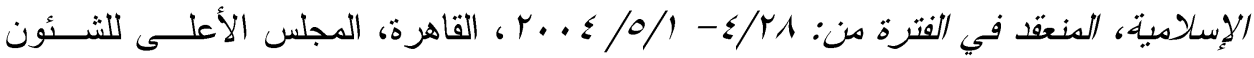

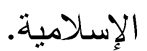

1- السيد سلامة الخميسي (ب99 (1)): "تربية التسامح الفكري" صيغة تربوية مقترحة لمو اجهــة

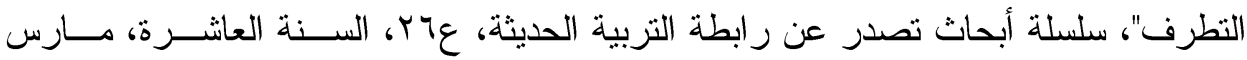
ب9919، الإسكندرية، دار المعرفة الجامعية.

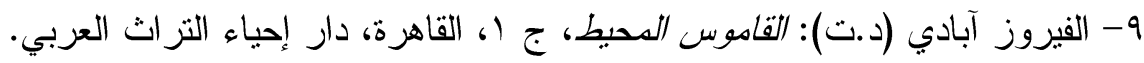

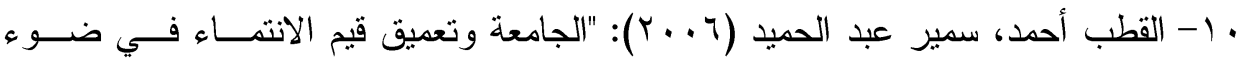

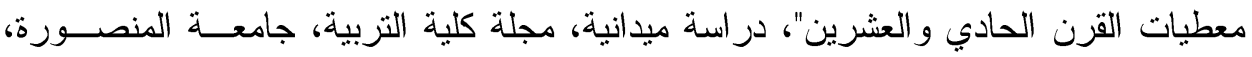

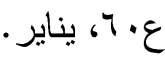
1) للتزجمة (r) ب)، القاهرة، المجلس الأعلى للتقافة. Y ب- رونالد روبرتسون (1991)): العولمة ل... النظرية الاجتماعية والثقافية الكونية، ترجمة:

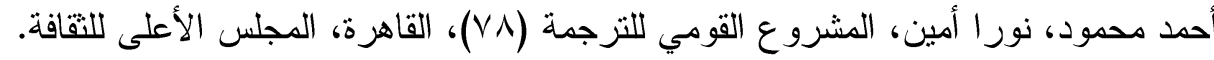

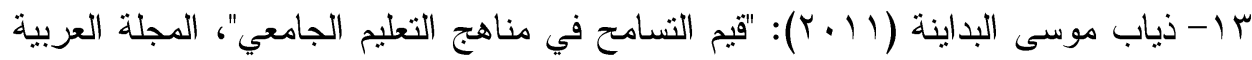

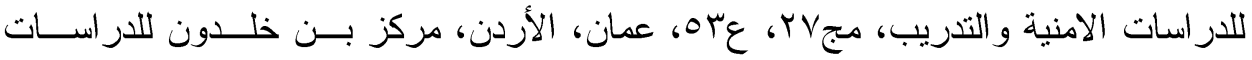

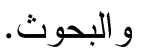

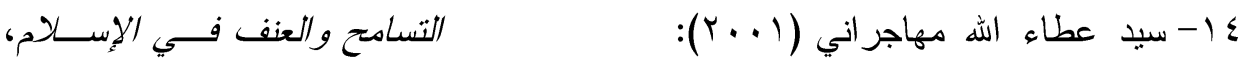


إجراعات مقترحة لتفعيل مسئولية الإدارة الجامعية نحو نشر ثقافة التسامح لاى طلابها

ترجمة: سالم كريم، بيروت، رياض الريس للكتب و النشر، إيريل.

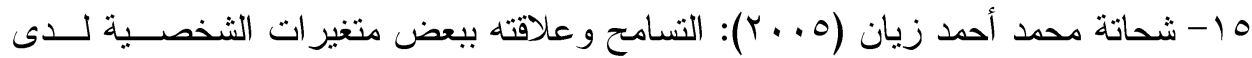
عينة من طلبة المرحلتين الثانوية و الجامعية، رسالة دكتور/ه، معهــــ الدراســات و البحــوث

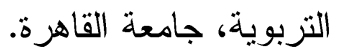

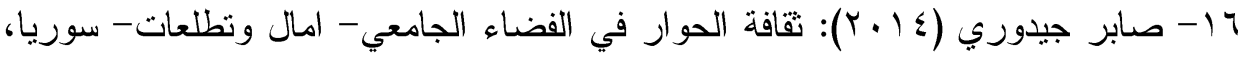
كلية التربية، جامعة دمشق.

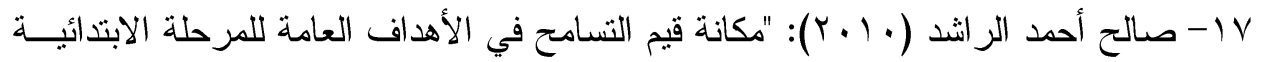
في دولة الكويت"، مجلة كلبة التربية، جامعة الإسكندرية، ع ( (1)، مج (· (r). 11 - عبد الرحمن النجار (7 (911): خطب الجمعة و العبيدين، ط7، القاهرة، دار المعارف. 9 1 19

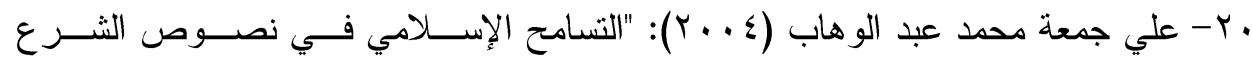

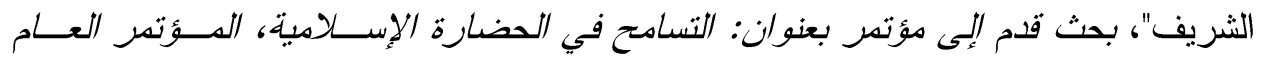

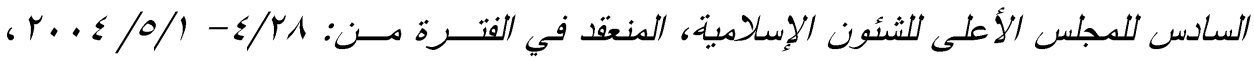
القاهرة، المجلس الأعلى للشئون الإسلامية.

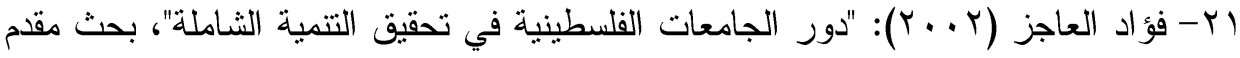

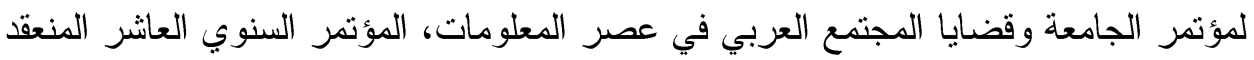

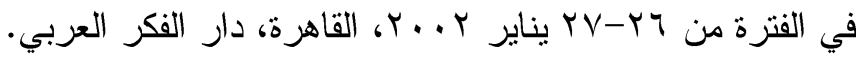

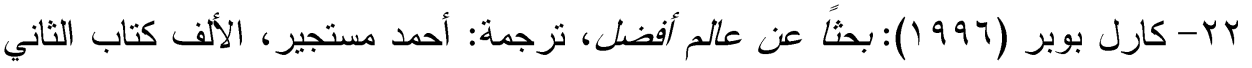

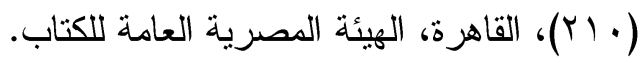

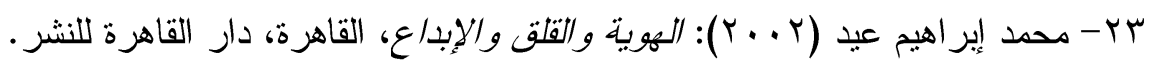

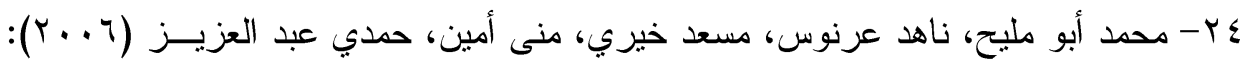

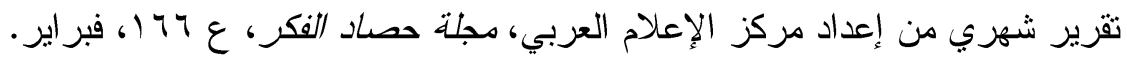

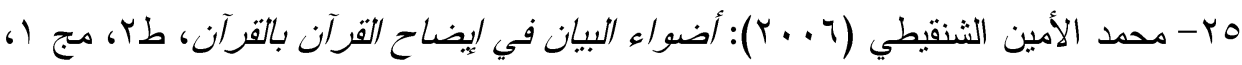
لبنان، بيروت، دار الكتب العلمية.

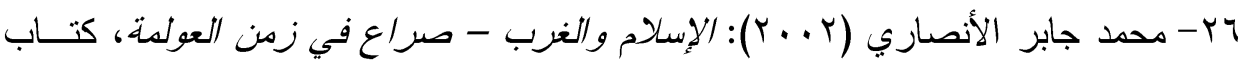

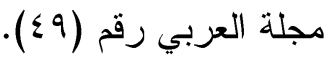

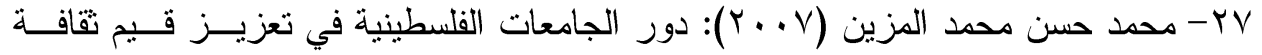

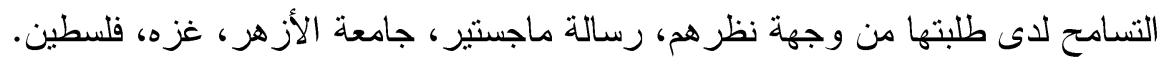

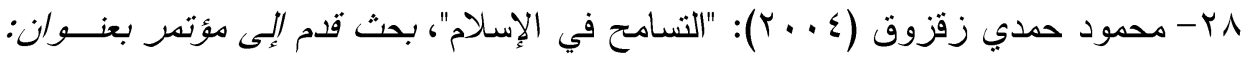


إجراعات مقترحة لتفعيل مسئولية الإدارة الجامعية نحو نشر ثقافة التسامح لاى طلابها

التسامح في الحضارة الإسلادية، المؤتمر العام السادس للمجلس الأعلى للثــئون الإســلامية،

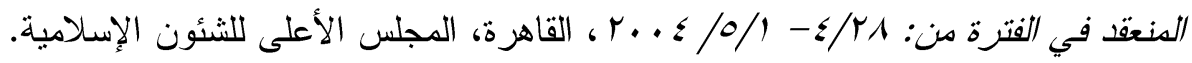

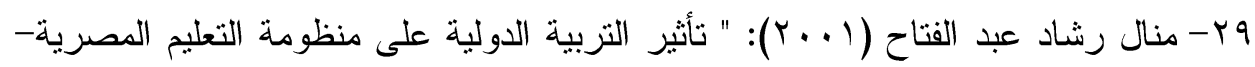

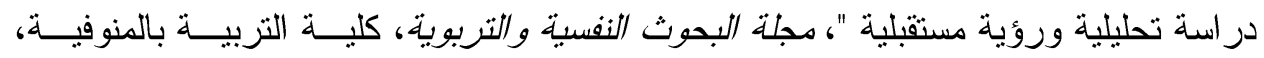

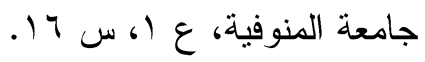

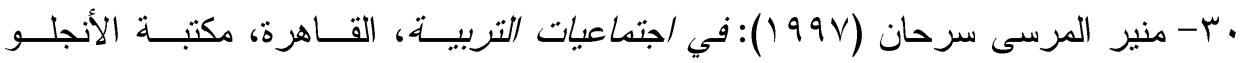

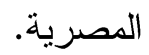

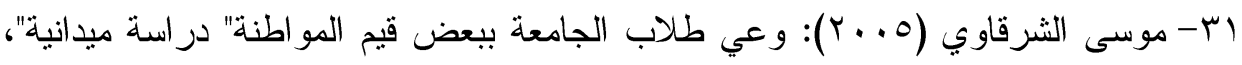

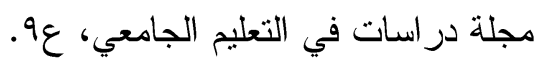

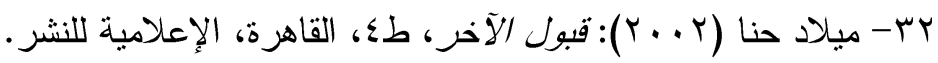

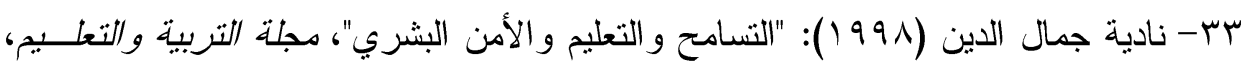
العدد (r (1)، أكتوبر 991 (1، تصدر عن المركز القومي (للبحوث التربوية.

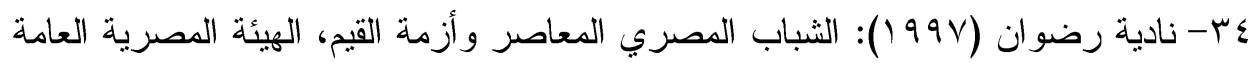

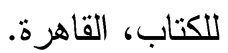

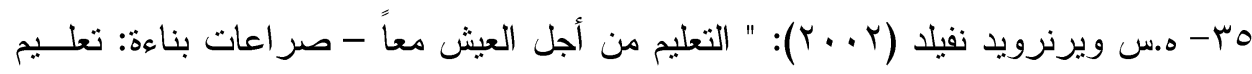

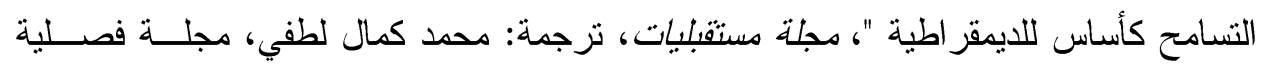

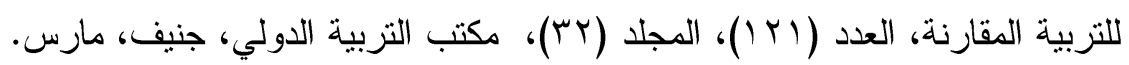

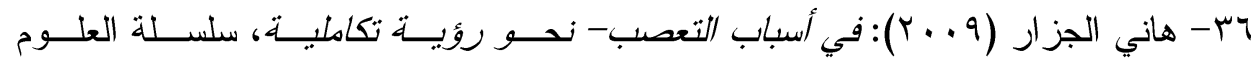
الاجتماعية، مكتبة الأسرة، الهيئة المصرية العامة للكتاب.

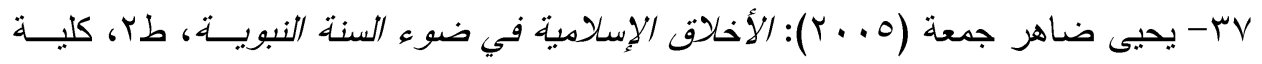

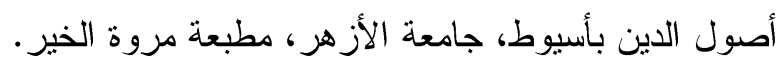

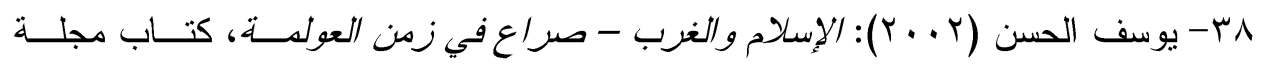

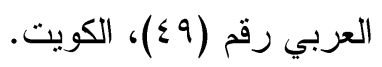

